\title{
Sand grain crushing and interface shearing during displacement pile installation in sand
}

\author{
Z. X. YANG ${ }^{*}$, R. J. JARDINE $\uparrow$, B. T. ZHU
}

\begin{abstract}
Particle crushing, shear banding, interface abrasion and migration of crushing products all have the potential to influence the behaviour of displacement piles in sands. This paper considers these particulate processes, reporting experiments with model displacement piles installed in uniform pressurised sand and parallel interface ring shear tests. The findings offer new insights into the mechanics of displacement piles in sands.
\end{abstract}

KEYWORDS: fabric/structure of soils; model tests; particle crushing/crushability; piles; sands; strain localisation; time dependence
Le broyage de particules, les bandes de cisaillement, l'abrasion sur l'interface, et la migration des produits du broyage sont tous susceptibles d'influer sur le comportement de piles de déplacement dans le sable. La présente communication se penche sur ces procédés particulaires, et rend compte d'expériences effectuées avec des maquettes de piles de déplacement installées dans du sable sous pression uniforme, et d'essais de cisaillement annulaire sur l'interface parallèle. Les résultats permettent de mieux comprendre la mécanique des piles de déplacement dans le sable.

\section{INTRODUCTION}

Field research with instrumented piles has led to greatly improved driven pile design approaches in sand (Lehane, 1992; Lehane et al., 1993; Lehane \& Jardine, 1994; Jardine \& Chow, 1996; Chow, 1997; Gavin \& Lehane, 2003a, 2003b; Clausen et al., 2005; Kolk et al., 2005a; Lehane et al., 2005; White et al., 2005; Gavin \& O'Kelly, 2007; Jardine \& Chow, 2007). Key factors that are now appreciated include: the importance of sand state (conveniently expressed by local cone penetration test (CPT) resistance $\left.q_{\mathrm{c}}\right)$; the interface shear friction angles, $\delta^{\prime}=\tan ^{-1}$ $\left(\tau / \sigma_{n}^{\prime}\right)$, that depend on the sand, the interface material and its roughness; the pile type (closed, pipe or H section); and the relative depth $(h)$ of the pile tip below any given point on the shaft, usually considered as $h / R$ or $h / D$ (where $R$ and $D$ are radius and diameter). The sharp reductions in local radial effective stress with increasing $h / R$ seen in field tests with the Imperial College instrumented pile (ICP) were interpreted by Lehane (1992) and Chow (1997) as resulting primarily from the combination of the strain paths (Baligh, 1985) developed around the tip and extreme load cycles imposed by jacking or driving. Possible time effects were also noted. A generally unappreciated tendency for piles driven in sands to gain shaft capacity with time has been reported that may be the result of interactions between creep and circumferential arching (Åstedt et al., 1992; Chow et al., 1997; Jardine et al., 2006).

Recent laboratory model investigations provide further insights into the influences of state, particle crushing, abrasion at the pile-sand interface and cyclic shaft loading; see for example Klotz \& Coop (2001), White \& Bolton (2004) and White \& Lehane (2004). Klotz \& Coop (2001) noted

Manuscript received 13 February 2009; revised manuscript accepted 23 November 2009.

Discussion on this paper closes on 1 November 2010, for further details see p. ii.

* Department of Civil Engineering, Zhejiang University, China, formerly Imperial College London, UK.

$\dagger$ Department of Civil and Environmental Engineering, Imperial College, London, UK.

\$ Arup Pty Ltd, Queensland, Australia, formerly Imperial College London UK.

§ Laboratoire Sols, Solides, Structures-Risques, Institut National Polytechnique de Grenoble, France. significant particle breakage close to the shafts of relatively smooth aluminium piles during monotonic penetration into silica and carbonate sands in centrifuge tests, but did not quantify the grading changes. Shaft interface friction characteristics were affected by particle breakage, which were related to the sands' states and pile base resistances. Klotz \& Coop suggested that their aluminium piles' low shaft friction angles $\left(\delta^{\prime}\right.$ values of $\left.6-18^{\circ}\right)$ might not apply to rougher steel or concrete industrial piles.

White \& Bolton (2004) report detailed particle image velocimetry (PIV) measurements of the displacements and strain paths developed around the base of relatively smooth aluminium alloy 'plane strain' penetrometers during monotonic jacking into silica and carbonate sands that had been pressurised and partially unloaded. Their measurements, which concentrated on the zone located from ten penetrometer widths $(B=16 \cdot 1$ and $32.2 \mathrm{~mm})$ below the tip to $2 \cdot 5 B$ above, identified four stages of straining in elements located initially beneath the tip

(a) intense active straining (axial compression, lateral extension) as the tip approaches

(b) lateral extension, axial strain reversals and intense vertical shearing just before the tip arrives

(c) lateral strains and vertical shear strains increasing as the pile passes

(d) further compaction close to the shaft and significant tensile horizontal strain increments in the surrounding sand as the tip advanced from $h=0$ to $2 \cdot 5 B$.

Minimal further straining was reported at higher $h / B$ ratios. The strain reversals were considered highly significant and were in broad agreement with aspects of constant volume strain path analyses by Baligh (1985). White \& Bolton (2004) noted considerable crushing ahead of their penetrometer tip, where a conical mechanism incorporating shear bands was identified. The broken material displaced by the advancing tip formed shear zones either side of the penetrometer shaft. Significant volumetric compression was interpreted within the crushed sand but measurements of grading changes and interface shear behaviour were not reported. White \& Bolton (2002) also suggested that particle breakage near the shaft might lead to outward migration of fines into surrounding void spaces that could allow further radial contraction and normal stress reductions at the shaft. Com- 
paction within the shear zone and migration of fines were interpreted as contributing to the ' $h / R$ effect' seen in field tests.

Kishida \& Uesugi (1987) reported that sand interface shearing angles are controlled by the ratio of the interface roughness $R$ to the median grain size $D_{50}$. Focusing primarily on peak resistance and steel interfaces, $\tan \delta^{\prime}$ varied linearly with $R / D_{50}$, up to the limit $\delta^{\prime}=\varphi^{\prime}$. Lings \& Dietz (2005) normalised direct shear $\delta^{\prime}$ by $\varphi^{\prime}$ values obtained at the same state, finding a unique relationship with relative roughness. Instrumented field tests prove that the post-peak, constant volume, $\delta_{\mathrm{CV}}^{\prime}$ (which is independent of initial relative density) controls shaft resistance in sand (Lehane et al., 1993). Direct shear tests with steel interfaces having the roughness of typical steel piles $\left(5 \mu \mathrm{m}<R_{\mathrm{CLA}}<10 \mu \mathrm{m}\right)$ show $\delta_{\mathrm{CV}}^{\prime}$ falling with $D_{50}$ (Jardine et al., 1992). Following the Centre for Civil Engineering Research and Codes, CUR (2001), Kolk et al. (2005a) argued that such tests fail to capture particle crushing and interface abrasion that takes place in the field. They proposed adopting $\delta_{\mathrm{CV}}^{\prime}=29^{\circ}$ for the practical design of steel piles driven in silica sands, while Kolk et al. (2005b) noted (on extraction after prolonged ageing) a zone of modified soil adhering strongly to the shaft of the large-scale EURIPIDES open-pipe steel piles driven in dense marine sand.

Unlike direct shear tests, ring shear interface experiments can impose shear displacements as large as those experienced by pile shafts. Jardine et al. (2005) recommended such tests to aid practical design, noting the need to specify the appropriate interface material, roughness and field stress levels. Ho (2007) conducted multiple ring-shear tests on steel interfaces (with roughnesses similar to those of industrial piles) and a range of dry silica media, confirming that sand-steel $\delta_{\mathrm{CV}}^{\prime}$ values are shear displacement dependent and considerably higher than Klotz \& Coop's (2001) centrifuge values for smoother aluminium interfaces. A fractured sand zone developed at the ring-shear interface under high stresses, the thickness of which was related to the initial grain size. However, as suggested by Kolk et al. (2005a), the $\delta_{\mathrm{CV}}^{\prime}$ values of differently sized media tended to converge after several metres of displacement.

The current paper explores the above processes with stainless steel cylindrical, appropriately rough, piles that were jacked, non-monotonically, into pressurised sand. A cylindrical calibration chamber was employed to avoid the plane strain boundary problems described by White \& Bolton (2004). The focus is on particle-scale experiments that tracked the detailed evolution of the sand's make-up and the pile's surface texture at points up to $1 \mathrm{~m}$ (or 54R) above the pile tip. Parallel interface ring-shear tests are reported that follow the evolution of the same features of interface behaviour, offering new insights into displacement piles in sands.

\section{PILE EXPERIMENTS}

The pile experiments were conducted at the Institut Polytechnique de Grenoble (INPG) in the calibration chamber illustrated in Fig. 1. The model piles had the same diameter and conical tip details as a standard electrical CPT cone. Intensive systems of instrumentation were installed to characterise the stress regime and will be reported separately.

Multiple pile tests have been performed, filling the chamber with 'virgin' NE34 Fontainebleau sand for each test, prior to loading to $150 \mathrm{kPa}$ through the upper membrane cell and progressing to pile installation. The air pluviation system was adjusted to obtain targets of $e=0.62, D_{\mathrm{r}}=72 \%$. NE34 has the index properties given in Table 1. Direct shear tests with initial $D_{\mathrm{r}}=72 \%$ and $50<\sigma_{n}^{\prime}<500 \mathrm{kPa}$ gave peak and critical state $\varphi^{\prime}$ values of $35.2^{\circ}$ and $32.8^{\circ}$ at overconsolidation ratio, $\mathrm{OCR}=1$. Independent direct shear and triaxial tests by Marechal (1999) and Gaudin et al. (2005) gave peak $\varphi^{\prime}=37 \cdot 4^{\circ}$ and $36 \cdot 5^{\circ}$ respectively. Ring shear steel interface tests by Ho (2007) showed $\delta_{\mathrm{CV}}^{\prime}$ varying with displacement between around $25^{\circ}$ and $27^{\circ}$ over the range $100<\sigma_{n}^{\prime}<800 \mathrm{kPa}$; similar trends are reported later from tests with stainless steel interfaces.

In the present study the focus is primarily on the miniICP2 test (ICP, inductively coupled plasma), which penetrated $990 \mathrm{~mm}$ during installation, adding some further information gathered in the similar mini-ICP3 experiment. Static and cyclic pile load tests were performed after 139 days of ageing on mini-ICP2, which ended with 100 largedisplacement cyclic tests that increased pile penetration by $100 \mathrm{~mm}$, before dismantling and careful exhumation. MiniICP3 employed an upper membrane with a reduced central annular space $(50 \mathrm{~mm}$ internal diameter (ID) instead of $200 \mathrm{~mm}$ ), which led to more uniform shallow stress conditions. The pile experienced a less vigorous programme of cyclic testing, after a 53-day ageing period that led to a net upward displacement of $20 \mathrm{~mm}$ and a final tip depth of $970 \mathrm{~mm}$.

Independent standard CPT tests were conducted under $150 \mathrm{kPa}$ utilising both upper membrane designs; see Fig. 2. Both $q_{\mathrm{c}}$ traces present quasi-constant $21 \pm 2 \mathrm{MPa}$ sections, while the friction ratios, $f_{\mathrm{r}}$, fell around $1 \%$. However, the $50 \mathrm{~mm}$ ID membrane led to a steady trace being achieved at a much shallower depth.

The instrumented piles were air abraded to a centre-line average roughness $R_{\mathrm{CLA}} \sim 4 \mu \mathrm{m}$ (confirmed by multiple Hobson-Rank Talysurf measurements) which were far rougher than those adopted for the laboratory models discussed earlier. In order to match non-monotonic field installation, jack strokes were applied that involved either 5 or $20 \mathrm{~mm}$ of displacement (in mini-ICP2 and 3 respectively) before releasing the head load and allowing the shaft to 'rebound' and develop a partial shaft failure in tension. Soil on the pile axis experienced intense axial compression as the tip approached, with vertical stress levels approaching the CPT $q_{\mathrm{c}}$ magnitudes.

\section{MODEL PILE OBSERVATIONS AND MEASUREMENTS}

The piles and dry sand were carefully exhumed after testing. As shown in Fig. 3, a relatively thin annular skin (zone 1) of highly compacted and sheared grey soil adhered to the shaft, possibly analogous to that reported by Kolk et al. (2005b). A sharply defined boundary existed between zone 1, which naturally adhered to the shaft, and the surrounding sand. When a mist spray of water was applied to the sand around the shaft, a thicker band of buff-coloured sand was able to adhere unsupported as a result of capillary suction. Noting that, for any given wetting history, the maximum sustainable suction rises sharply as pore diameter falls (see for example Lane \& Washburn, 1946), the 'adherence limit' provides a convenient criterion to define and sample a second annular region. As shown later, the adherence test corresponds to a consistent proportion of crushed fine material. Samples from zones 1 and 2 were taken with curved tools. The non-adhering buff-coloured sand found at greater radius (zone 3 ) was sampled by local excavation.

The sampling locations are summarised in Fig. 4. Thirteen small (10-20 g) and larger 'bulk' specimens were collected around mini-ICP2 for grading analyses. With mini-ICP2, the zone 1 thicknesses were measured with a thin metal scale allowing a resolution of around $0.2 \mathrm{~mm}$; averages from multiple measurements led to the zone 1 thickness profile shown in Fig. 4(b). A better imaging approach was adopted 


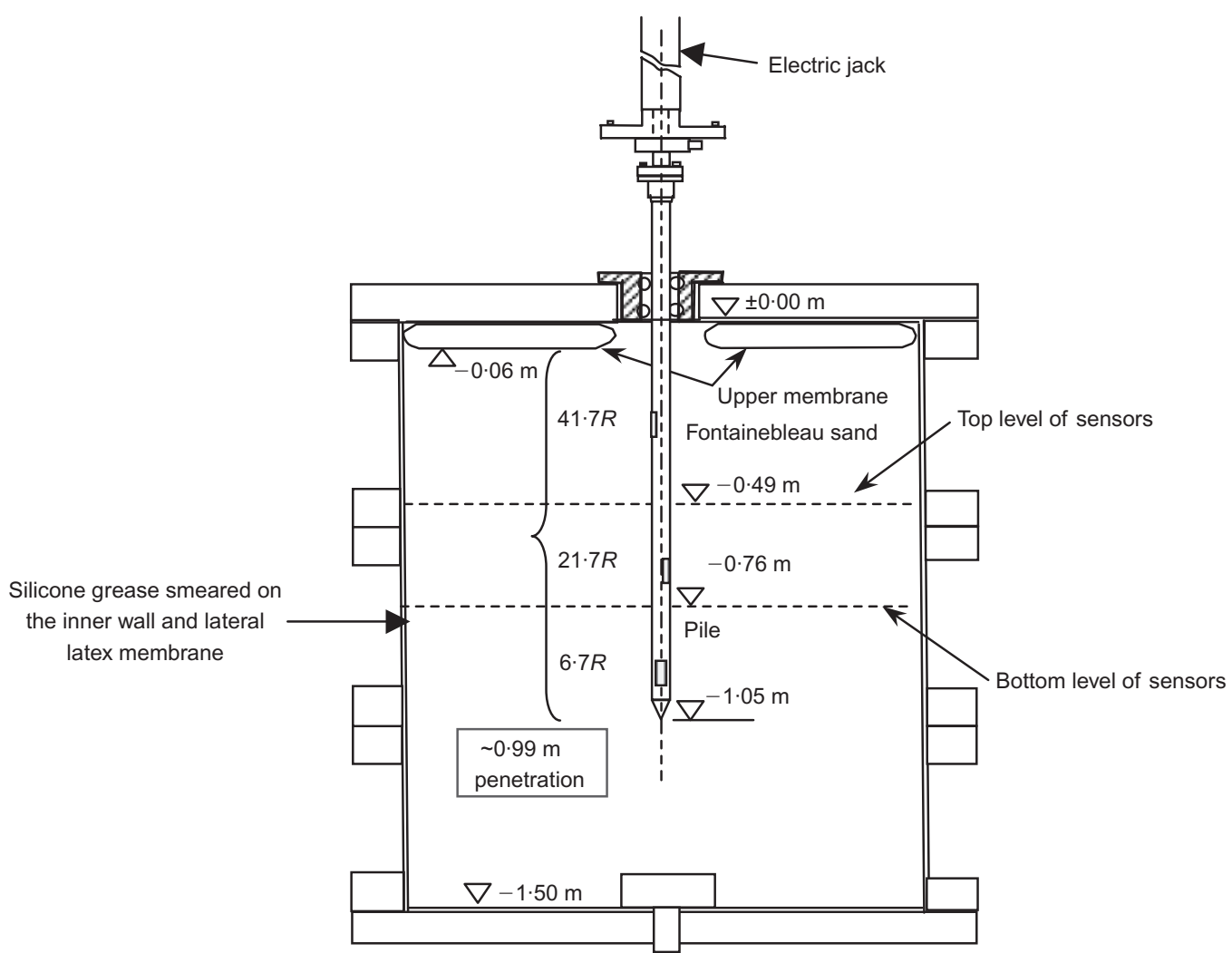

(a)

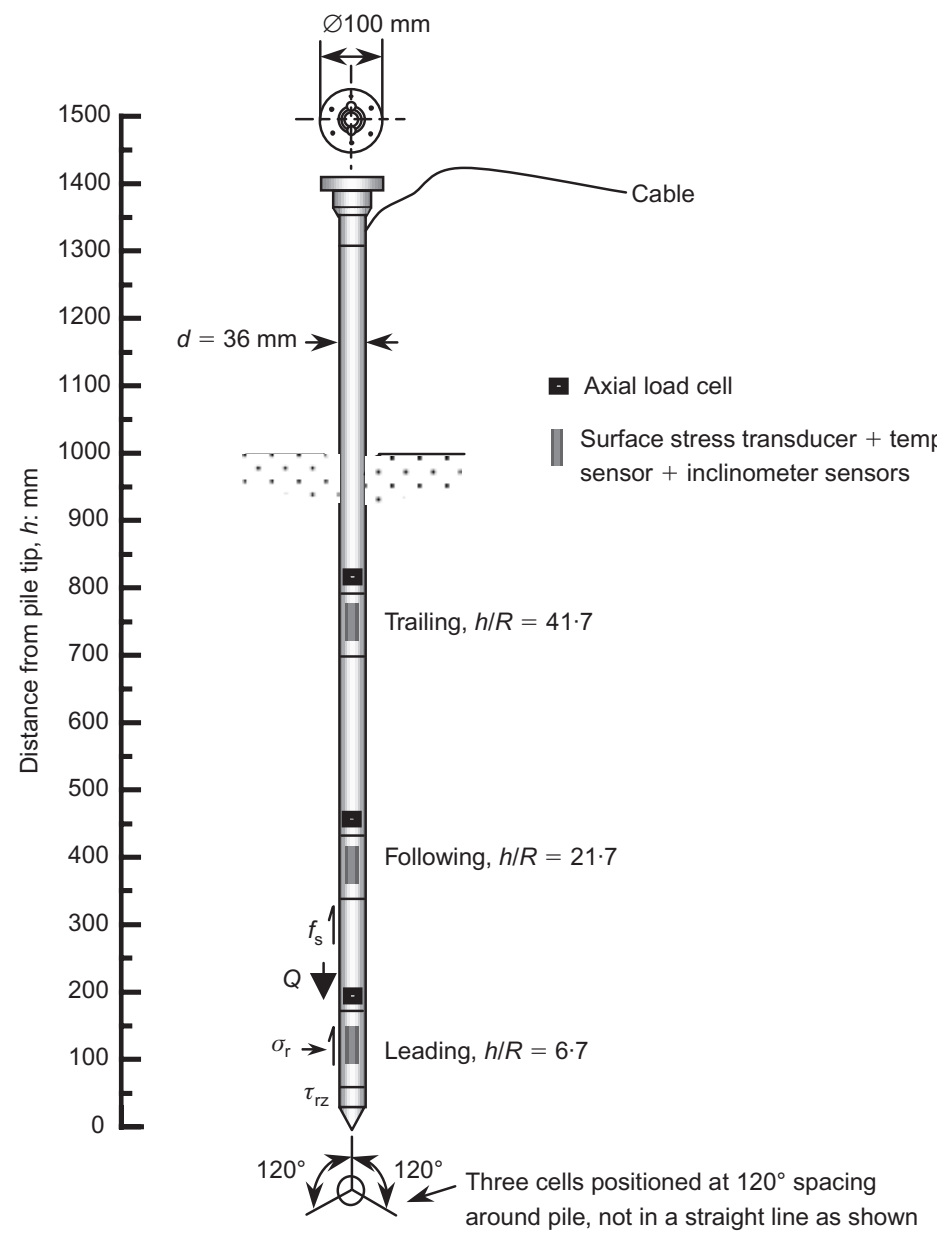

(b)

Fig. 1. (a) General arrangement for pile test mini-ICP2 in $1200 \mathrm{~mm}$ ID chamber: note the zero lateral displacement vertical boundary condition. (b) General pile configuration for mini-ICP2 
Table 1. Index properties of Fontainebleau NE34 sand

\begin{tabular}{l|c|c|c|c|c|c|c|c}
\hline Grain shape & $\mathrm{SiO}_{2}: \%$ & $\begin{array}{c}\text { Specific gravity, } \\
G_{\mathrm{s}}\end{array}$ & $D_{10}: \mathrm{mm}$ & $D_{50}: \mathrm{mm}$ & $D_{60}: \mathrm{mm}$ & $\begin{array}{c}\text { Coefficient of non- } \\
\text { uniformity, } C_{\mathrm{u}}\end{array}$ & $e_{\max }$ & $e_{\min }$ \\
\hline Sub-angular & $99 \cdot 70$ & $2 \cdot 65$ & $0 \cdot 15$ & 0.21 & $0 \cdot 23$ & 1.53 & 0.90 & 0.51 \\
\hline
\end{tabular}

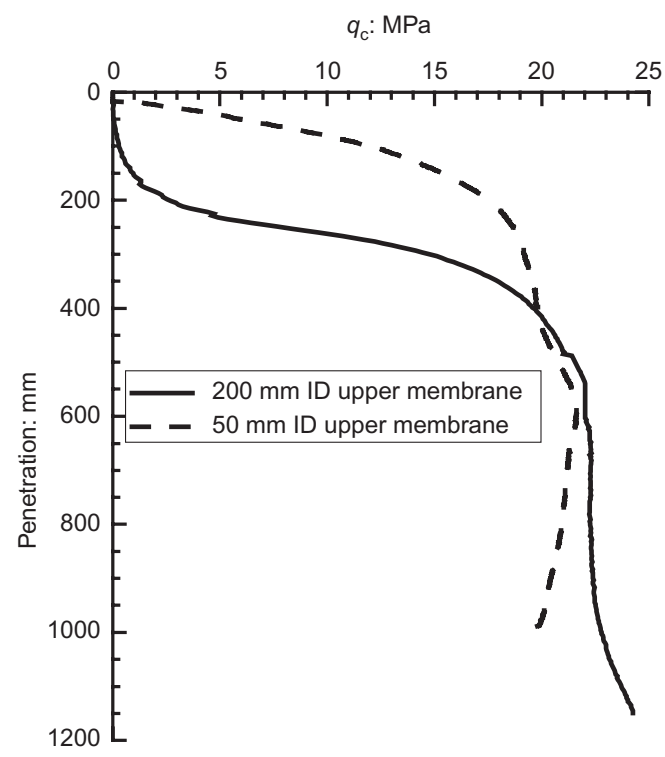

Fig. 2. Cone resistance, $q_{\mathrm{c}}$ traces from tests with alternative upper membrane designs

for mini-ICP3. High-resolution scaled digital photographs were taken of 44 samples from 16 locations and processed with the GIMP software (http://www.gimp.org) leading to the less scattered trend in Fig. 4(b). While the measurement resolution was also constrained by the particle dimensions (with $D_{90} \approx 0.3 \mathrm{~mm}$ ) both tests show zone 1 growing in thickness above the pile tip, increasing with $h$ from around 0.9 to $1.8 \mathrm{~mm}$, and 0.5 to $0.8 \mathrm{~mm}$, in mini-ICP2 and 3 respectively. No grey zone 1 soil was observed over the top $200 \mathrm{~mm}$ of sand in mini-ICP2, where $q_{\mathrm{c}}<3 \mathrm{MPa}$, despite the large local shear displacements. However, zone 1 material was present from $50 \mathrm{~mm}$ downwards in mini-ICP3, where the modified upper membrane led to CPT $q_{\mathrm{c}}$ exceeding $5 \mathrm{MPa}$ at this particular depth (see Fig. 2). Additional caliper measurements indicated a zone 1 thickness of $\approx 0.5 \mathrm{~mm}$ around mini-ICP3 at $100 \mathrm{~mm}$ depth. Zone 1 varies in thickness from $2 \cdot 4 D_{50}$ (close to the tip, in the test with less cyclic loading), to $8 \cdot 6 D_{50}$ at points $700 \mathrm{~mm}$ above the tip in miniICP2, which experienced repeated large-displacement cyclic loading. White \& Bolton (2004) also report a crushed soil interface zone $2-3 \mathrm{~mm}$ (or $2 \cdot 4-3 \cdot 6 D_{50}$ ) wide in their plane strain penetration tests on Leighton Buzzard sand, which is coarser than NE34, with $D_{50}=0.84 \mathrm{~mm}$.

The 44 small mini-ICP3 zone 1 samples were weighed after oven drying. Volumes were assessed from the dimensions and void ratios calculated for the 13 depths, which show considerable scatter (standard deviation $\approx 0.23$ ) due to measurement limitations, but no clear trend with depth. The mean $e_{\text {final }} \approx 0 \cdot 36$, indicates a net volume compression of $16 \%$ relative to the initial $e_{0}=0 \cdot 62$, which may be compared with the lower limit of $10.5 \%$ interpreted by White \& Bolton (2004) after penetration tests into looser LBS sand (initial $D_{\mathrm{r}}=34 \%$ ). Small-scale laboratory maximum and minimum void ratio determinations on the authors' zone 1 samples show a slight increase in $e_{\max }$ (to 0.913 ) and a large fall in $e_{\min }$ (to $0 \cdot 310$ ) relative to the 'virgin' values quoted in Table 1. The modified values fall in the range expected for silty sand (Lambe \& Whitman, 1969). White \& Bolton (2004) reported a reduction in $e_{\max }$ from 0.80 to 0.61 in their crushed LBS 'nose-cone' material but report no value for $e_{\min }$.

The mini-ICP2 samples were too small to sieve, but could be analysed with the QicPic laser-based particle imaging system (manufactured by Sympatec $\mathrm{GmbH}$ ), which can resolve particles between $1 \mu \mathrm{m}$ and $20 \mathrm{~mm}$. The distributions obtained by different physical principles can vary. Fig. 5 shows the QicPic determinations of Feret minimum particle dimensions (defined as the minimum distance between two parallel tangents to the particle outline) and diameters from equal projection areas (EQPC) compared with the sieve analysis for fresh sand. The Feret minimum falls closer to the conventional grading and is adopted herein. However, it shows a finer particle distribution than sieving and it is important to maintain the same technique when making comparisons.

The fresh sand and mini-ICP2 distributions are compared in Fig. 6, whereas Fig. 7 presents the zone 2 and zone 3 results. The 'bulk' (mixed zone 1-2) results are presented in Fig. 8, whereas Fig. 9 presents typical microscope images and Fig. 10 gives average summary distributions. The profiles with depth of the $<100$ and $63 \mu \mathrm{m}$ zone 1 fractions are presented in Fig. 11. The particle crushing products fall primarily between 100 and $20 \mu \mathrm{m}$, comprising $\sim 20 \%$ of zone 1 , up to $8 \%$ of zone $2, \sim 5 \%$ in zone 3 and being
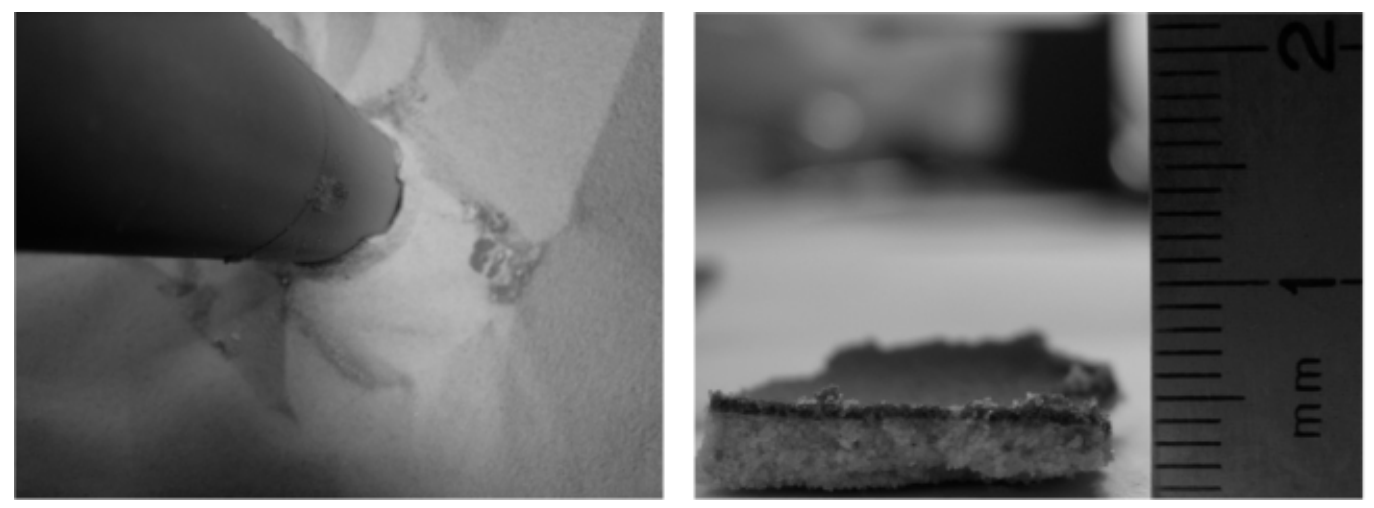

Fig. 3. Shear zone developed around the pile shaft 


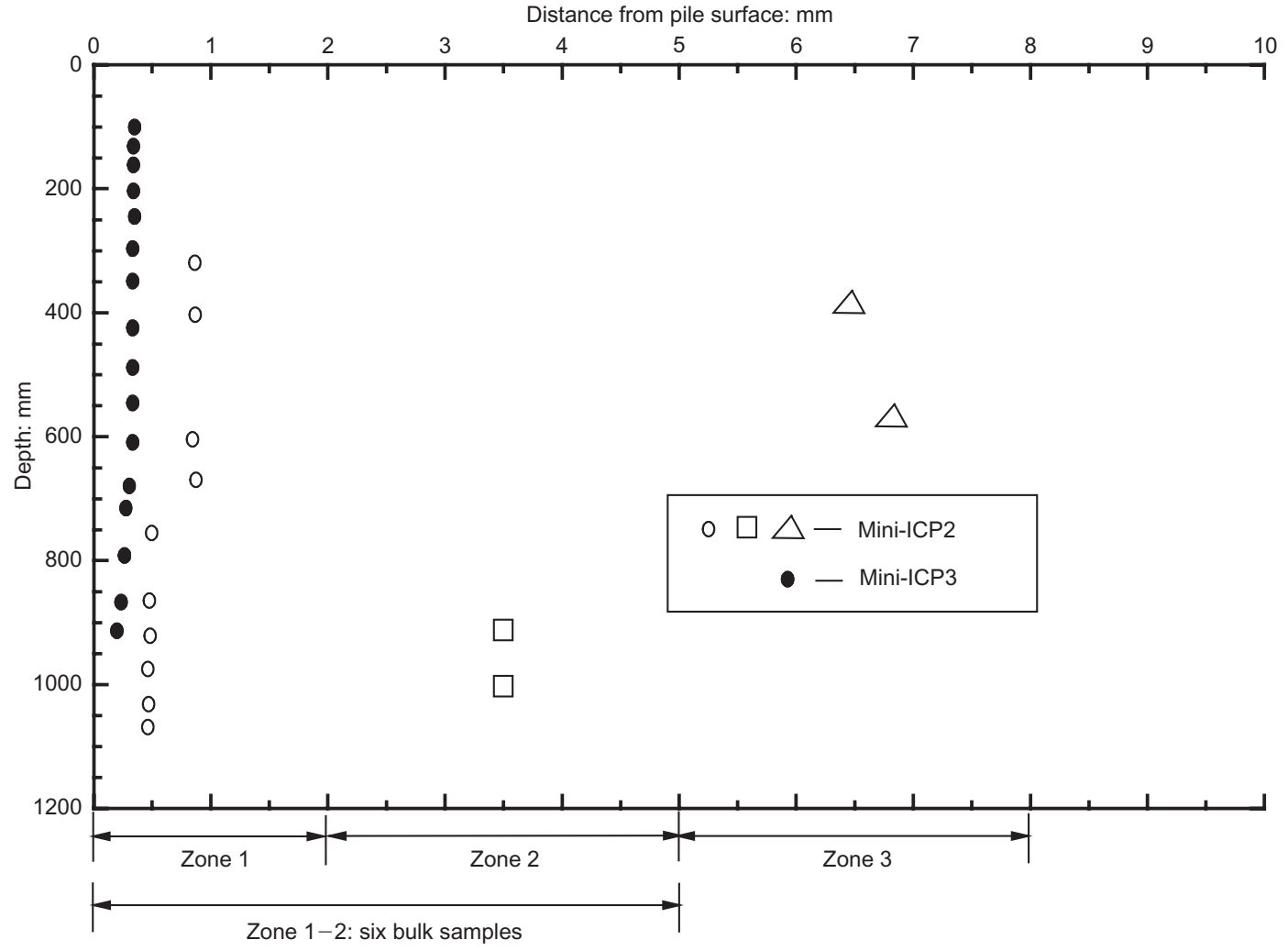

(a)
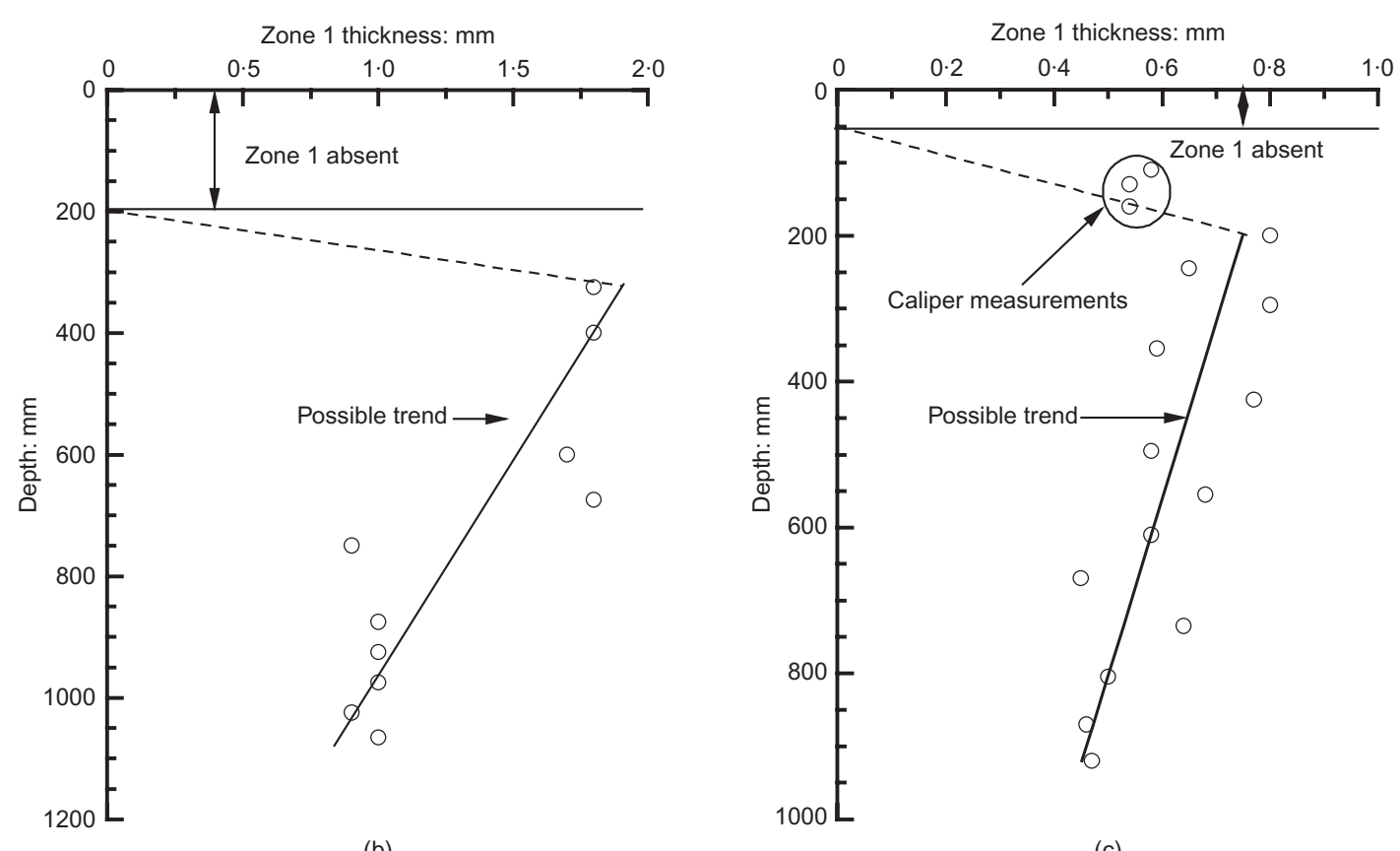

(b)

(c)

Fig. 4. Sampling and measurements for zone 1 in mini-ICP2 and mini-ICP3: (a) sampling locations: miniICP2 and mini-ICP3; (b) zone 1 profile: mini-ICP2; (c) zone 1 profile: mini-ICP3

absent in fresh sand. The suction-adherence criterion used to define zone 2 appears to lead to a narrow range with 6$8 \%<100 \mu \mathrm{m}$. The bulk samples taken below $300 \mathrm{~mm}$ show $<100 \mu \mathrm{m}$ fractions close to the expected averages $(\sim 11 \%)$, whereas those from $200 \mathrm{~mm}$ indicate minimal crushing with $<100 \mu \mathrm{m}$ fractions of just $1-2 \%$. While silt particles $(<20 \mu \mathrm{m})$ contribute only minor proportions by weight, zone 1 includes abundant individual silt grains adhering to sand particles (Fig. 9). Naturally, the variations in $D_{10}$ are more significant with depth, especially in zone 1, but they follow no clear trend. QicPic measurements of sphericity and convexity fell in broadly similar ranges (both $0.85 \sim 0.95$ ) across the particle size distributions of all samples.

The grey zone 1 colour probably results from intense surface abrasion changing the optical properties of the initially partially polished sand grains; see Fig. 9. While the piles' surface roughnesses were clearly reduced, measurements made with a digital vernier caliper (resolving to 


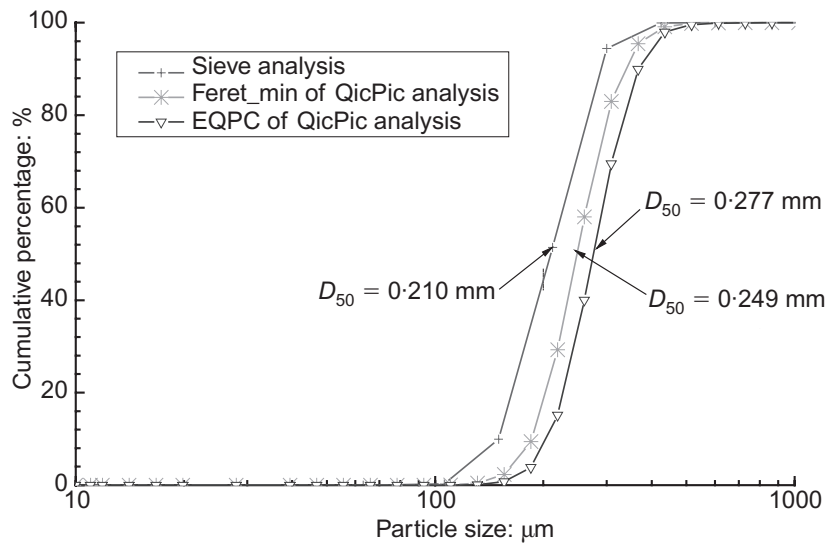

Fig. 5. Comparison of grading curves from different analysis methods for fresh Fontainebleau sand

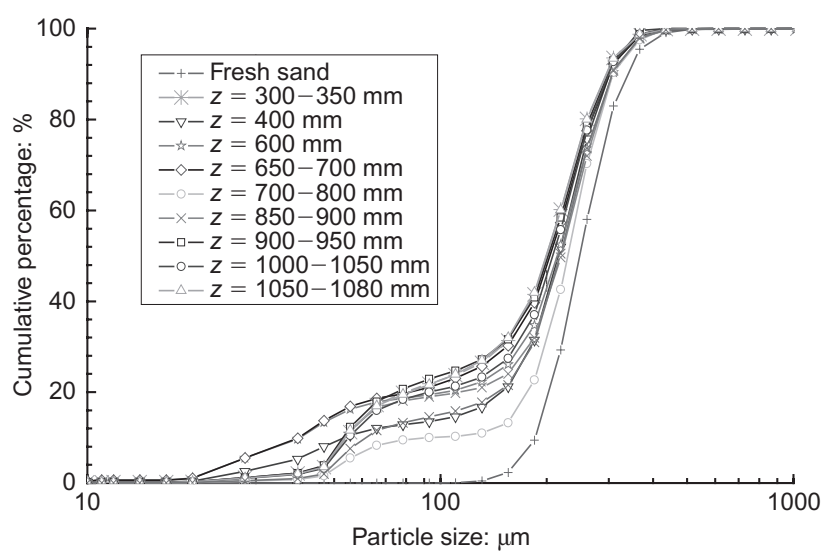

Fig. 6. Particle size distributions for zone 1 samples

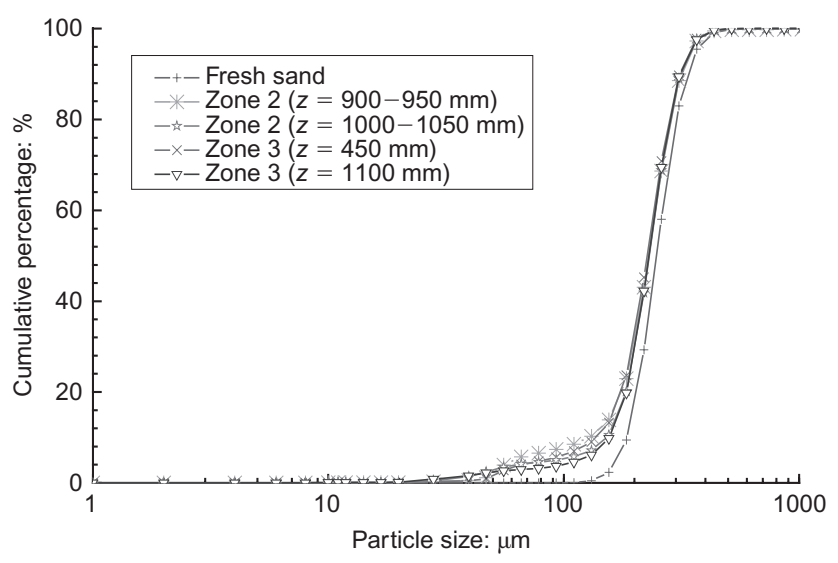

Fig. 7. Particle size distributions for zones 2 and 3 samples

$10 \mu \mathrm{m})$ did not show any evidence of significant net interface abrasion. An approximate calculation considering the asperity measurements described later indicates that $<0 \cdot 20 \%$ of the grey soil could consist of steel particles. Comparative $\mathrm{X}$-ray diffraction analyses confirmed that zone 1 comprises $99.6 \%$ quartz and has a spectrum close to that of fresh NE34 (99.7\% quartz).

\section{INTERPRETATION}

It is clear that pile installation in pressurised sand involves particle breakage and shear band formation. Noting that

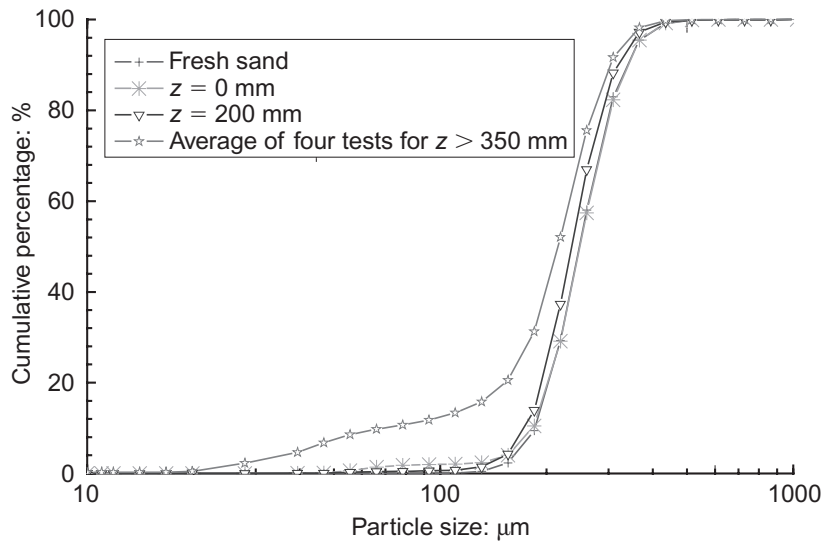

Fig. 8. Particle size distributions of bulk samples taken close to the pile with $z<200 \mathrm{~mm}$

zones 1, 2 and 3 were present at levels immediately above the base, breakage must commence beneath the tip (as argued by Klotz \& Coop (2001) and White \& Bolton (2004)), where the maximum end bearing pressures approach CPT $q_{\mathrm{c}}$. A fractured shear zone forms, provided $q_{\mathrm{c}}>5 \mathrm{MPa}$, when the $p_{\max }^{\prime}$ levels (estimated as $q_{\mathrm{c}}\left(1+2 K_{\mathrm{A}}\right) / 3 \sim 2.5 \mathrm{MPa}$ assuming constrained active shear failure with axial compression and radial expansion) match those for the onset of large-scale particle breakage in laboratory tests. The thickening of the zone 1 annulus with $h / R$ suggests additional breakage and abrasion linked to the accumulating effects of shearing and cycling applied during installation, which was further augmented (particularly in mini-ICP2) by later largedisplacement cyclic loading. The on-pile sensors showed an average interface shear angle just below $27^{\circ}$ falling within the range expected for industrial steel piles. Unlike the aluminium pile tests reported by Klotz \& Coop (2001), there was no clear evidence of any systematic variation of $\delta^{\prime}$ with depth.

As noted in the introduction, the radial stresses developed close to the pile are known to rise and fall dramatically (due to strain reversals and other factors) as the tip approaches and passes any given depth, falling to just $1-2 \%$ of $q_{\mathrm{c}}$ on the pile shaft when $h / R \approx 8$, as seen in field tests by Lehane et al. (1993) and Chow (1997). Similar features were noted in the mini-ICP tests, with radial stress measurements falling to just $2-3 \% q_{\mathrm{c}}$ at $h / R=6 \cdot 7$. These sharp stress reductions leave the sand in a heavily overconsolidated, and therefore dilatant, state at points above the pile tip. The same field tests indicated further decay of $\sigma_{\mathrm{r}}^{\prime}$ with increasing $h / R$ at points higher on the shaft, which has been ascribed to local contraction resulting from extreme cyclic loading, timedependent processes and shear zone densification (or growth) due to particle breakage.

Silica sands reveal high compressibility and markedly contractant responses to shearing under high-pressure triaxial testing (Coop, 2005). Fig. 12 shows a single high-pressure, $20 \mathrm{~mm}$ diameter, oedoemeter test on NE34 sand prepared with $e_{0}=0.62$, indicating also the initial $e_{\max }$ and $e_{\min }$ values and those from the zone 1 samples. The final oedometer test void ratio $(\approx 0.4)$ approaches, but lies above, that of the crushed zone 1 soil, which had experienced far more intensive shearing.

Silica sands also show a marked tendency to creep after the onset of particle breakage. Colliat-Dangus et al. (1988), Gasparre et al. (2003) and Coop (2005) found medium-term creep coefficients $c_{\alpha}=\mathrm{d} e / \mathrm{d} \log t$ in the range $0.005 \sim 0.012$, while the oedometer test on NE34 indicated medium-term $c_{\alpha} \approx 0.006$ at $\sim 50 \mathrm{MPa}$. Material that has experienced the extreme shearing imposed around the pile 


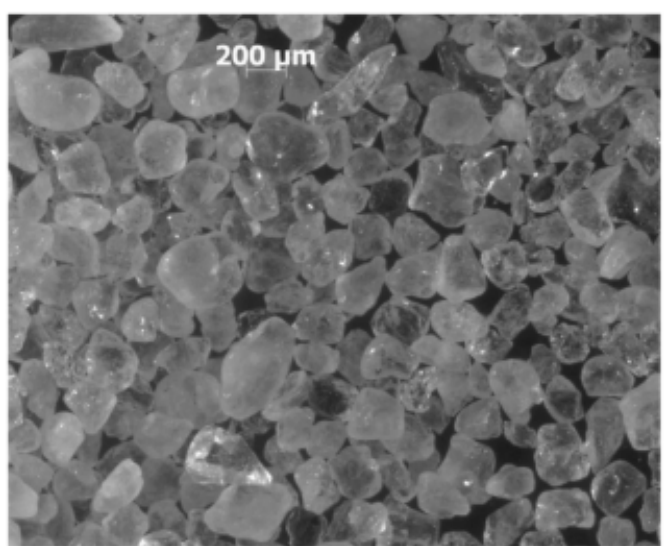

(a)

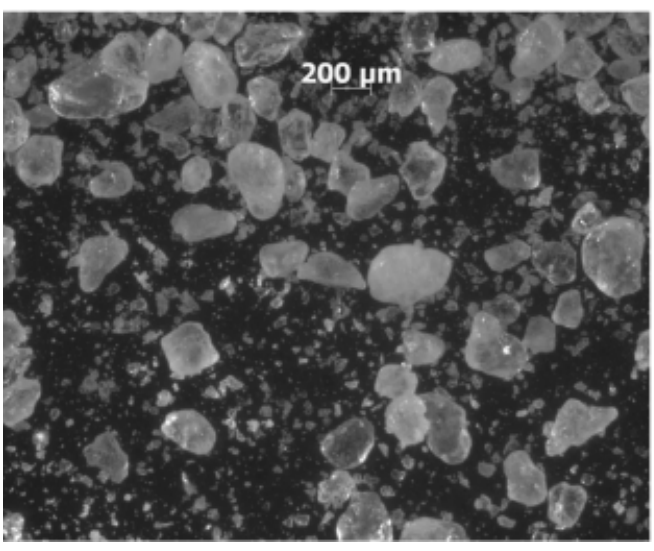

(c)

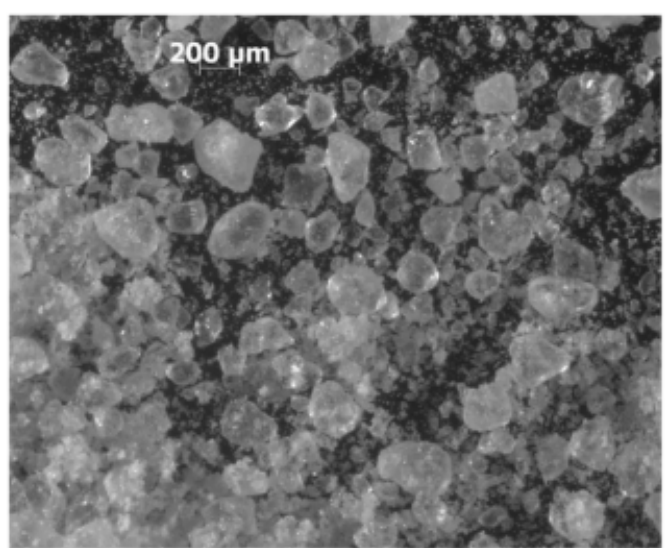

(b)

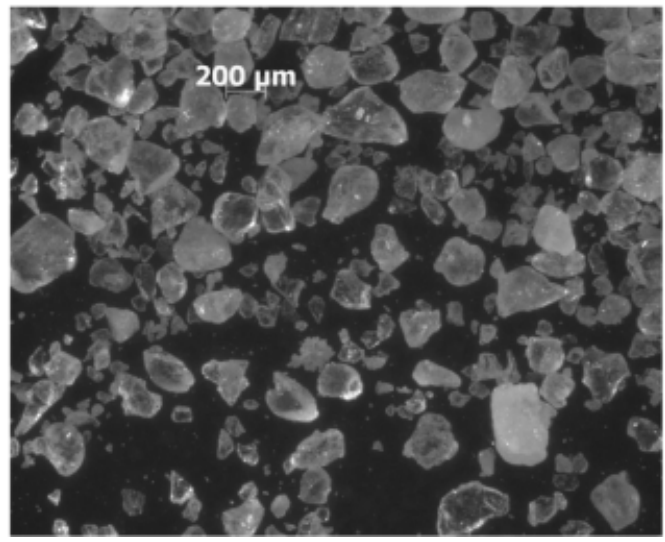

(d)

Fig. 9. Microscopic images showing modification of Fontainebleau sand: (a) fresh sand; (b) zone 1 sand; (c) zone 2 sand; (d) zone 3 sand

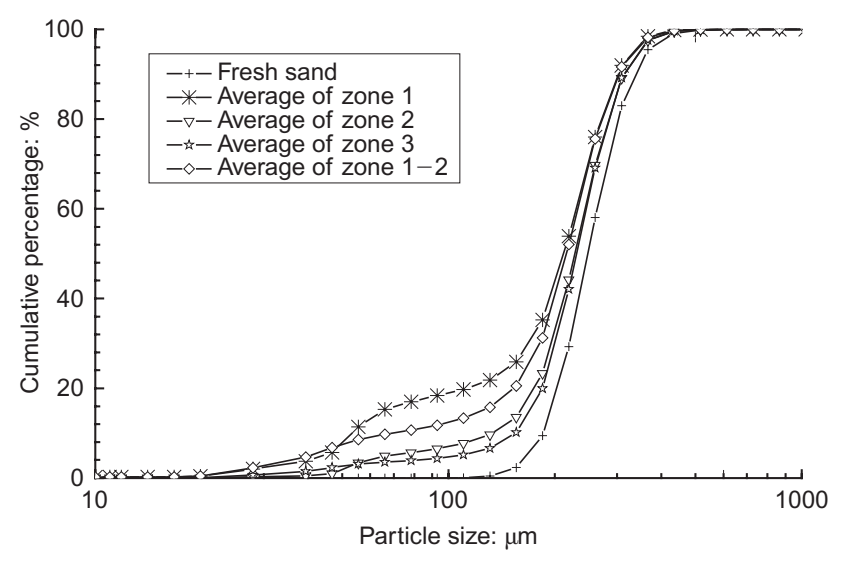

Fig. 10. Average distributions: zones 1,2 and 3 compared with fresh sand

tip can be expected to have strongly time-dependent mechanical behaviour.

The schematic representation in Fig. 13 summarises the key processes that are thought to be acting.

(a) Shear bands comprising breaking soil particles form beneath the pile tip that are displaced by continuing penetration to form the initial zone 1 annulus observed above the cone shoulder. The shear bands form over the surface of any conical tip, or over a 'nose cone' failure mechanism within the sand if the pile is flat ended (White \& Bolton, 2004).

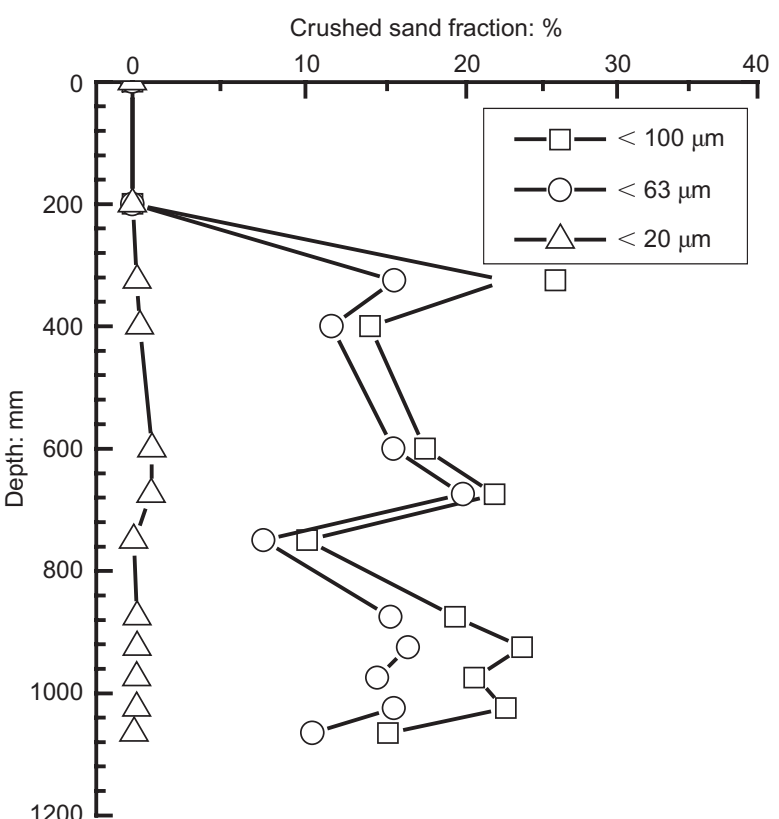

Fig. 11. Crushed sand fractions for zone 1

(b) Relating the pile tip's surface area to that of the cylindrical shaft per unit depth, indicates that the shear zone may be $\sqrt{3}$ thicker on the cone face than when spread out over the adjoining shaft (amounting to $\approx 0.9 \mathrm{~mm}$ thick or $4.1 D_{50}$ in mini-ICP3). Unfortunately this could not be confirmed. 


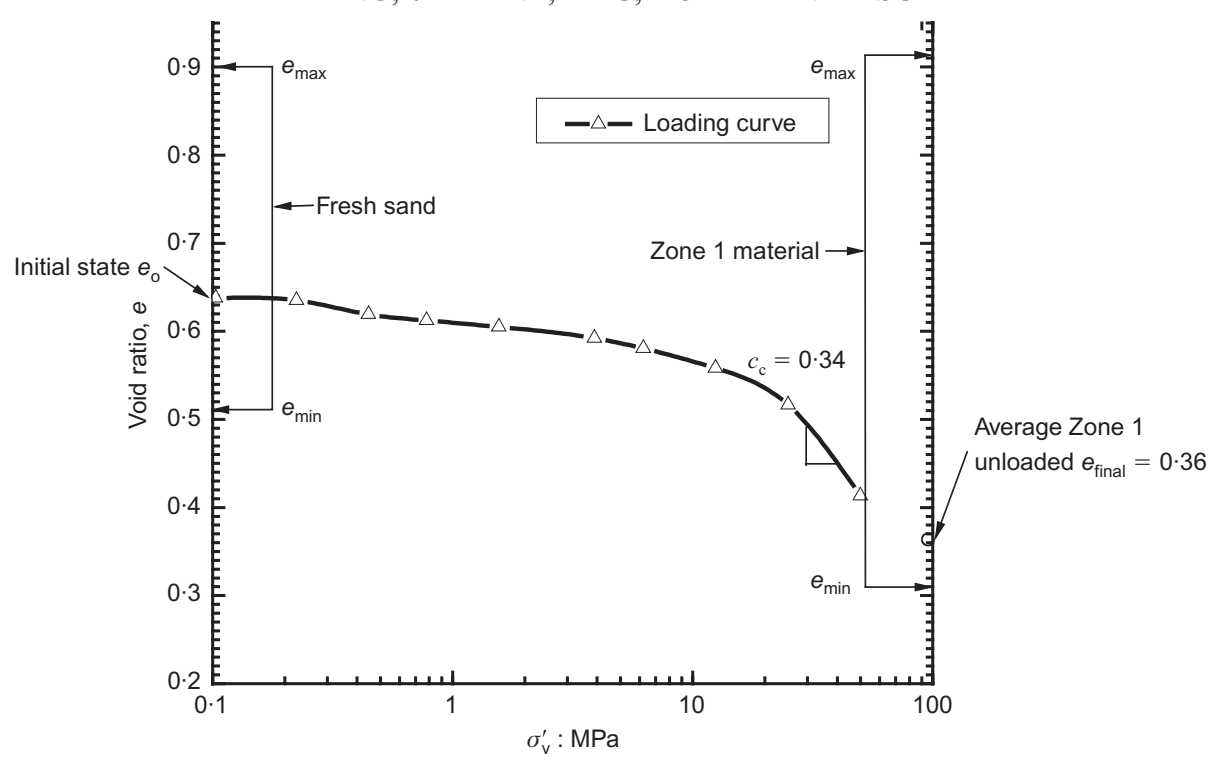

Fig. 12. Compression test on virgin NE34 sand, also showing index void ratios of fresh and fractured zone 1 sand samples

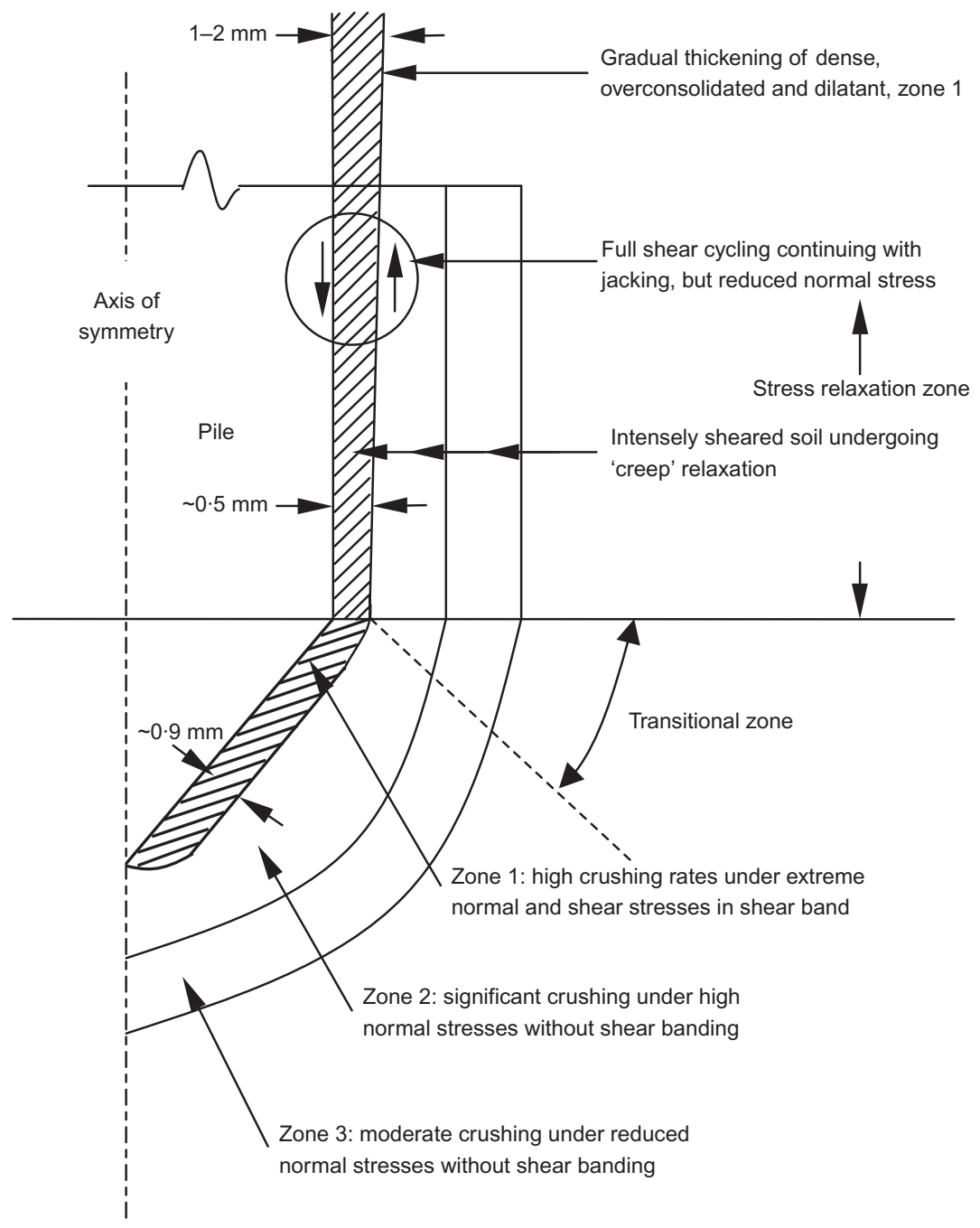

Fig. 13. Schematic development of zones 1 to 3 and their relationship to stress regime (not to scale)

(c) With the $36 \mathrm{~mm}$ diameter instrumented model piles, approximately $5 \%$ of the sand occupying the volume of the displaced sand is converted into zone 1 material beneath the pile tip level. A further $\sim 50 \%$ undergoes less breakage and becomes zone 2 sand, with the remainder falling into zone 3 - which also includes some soil from outside the pile's plan area. Projections might be made for other cases by assuming that the 
shear band's thickness is related to $D_{50}$ and is not affected by pile diameter.

(d) As the tip advances, the stress conditions applied to the breaking sand change from being loaded (ahead of the tip) to large strains and stresses under active conditions to being primarily kinematically constrained by (i) the zero lateral displacement boundary of the pile shaft and (ii) the relatively stiff response of the surrounding unloading sand mass. Strain reversals are imposed by the sand flow regime (Baligh, 1985) and local porosity may vary radially (White \& Bolton, 2004).

(e) If the surrounding soil mass exerted stress-controlled boundary conditions, significant creep straining would be expected within zones 1 and 2 during and after the intense compression, fracturing and shearing. If instead the boundary conditions involved negligible straining in the surrounding soil, sharp stress relaxation would ensue. As neither limiting case applies, a mixed creep and relaxation process can be expected with shear and volumetric straining developing around and immediately above the pile tip.

( $f$ ) The combined processes of strain reversals, creep and stress relaxation lead to stresses falling to between around 1.5 and $2.5 \% q_{\mathrm{c}}$ at the position of the lowest on-pile sensor. (g) Additional particle modification occurs at points above the tip that experience continuing (static and cyclic) shearing, with the zone 1 thickness increasing without any clear change in particle size distribution, or evidence of additional fines developing beyond the outwardly expanding zone 1 boundary. The zone also appears to be augmented by large-displacement shaft loading cycles.

(h) Combined stress relaxation and radially compressive creep are likely to continue within the shear zone as the pile penetrates further, acting in combination with compaction caused by shaft loading cycles to reduce gradually the local shaft radial stresses with growing $h / R$.

(i) The mechanism by which the zone 1 to 2 boundary remains sharply defined as it expands might involve fresh grains becoming entrained into the shear zone at a rate that balances its expansion, while mixing, abrading, fracturing and compaction continue to maintain the zone 1 particle distribution, state and colour.

(j) The zone 1 material is left highly compacted and overconsolidated at the end of installation, leading to strong local dilation when the shaft is loaded statically. Multiple Talysurf measurements were made of the piles' surface texture. Fig. 14 compares a typical 'pre-

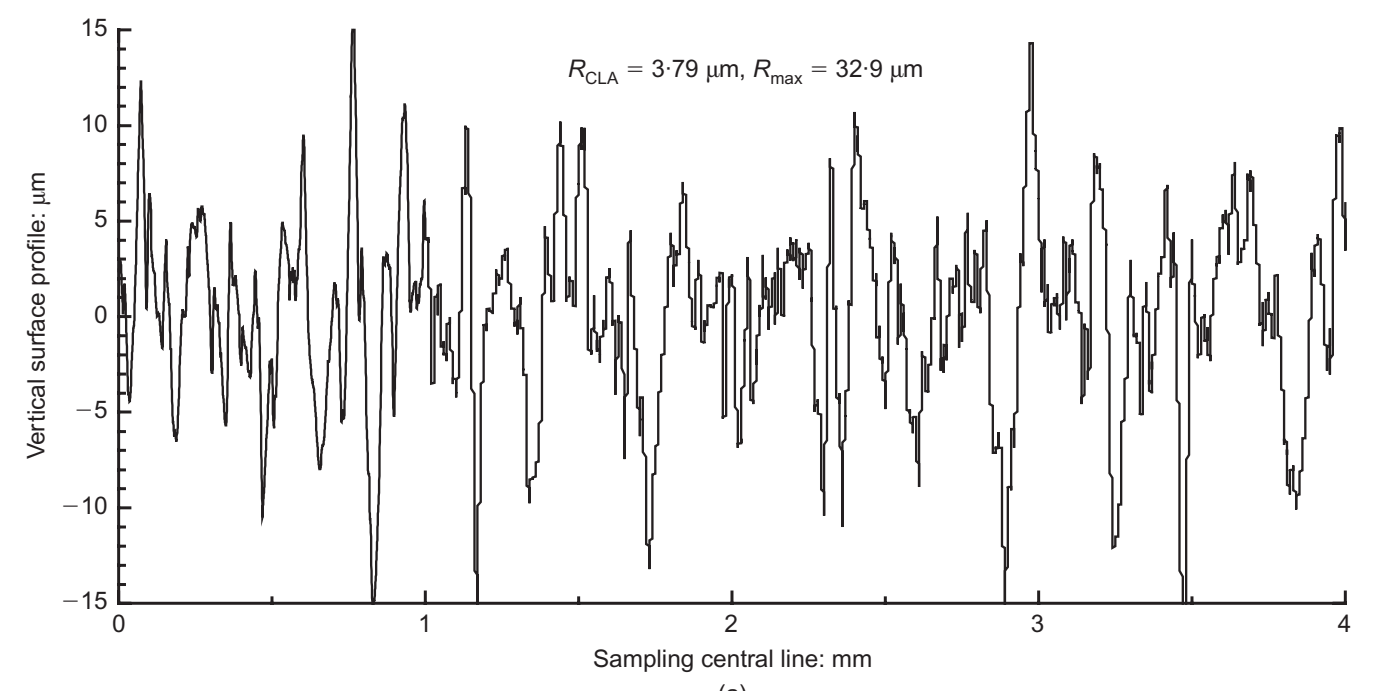

(a)

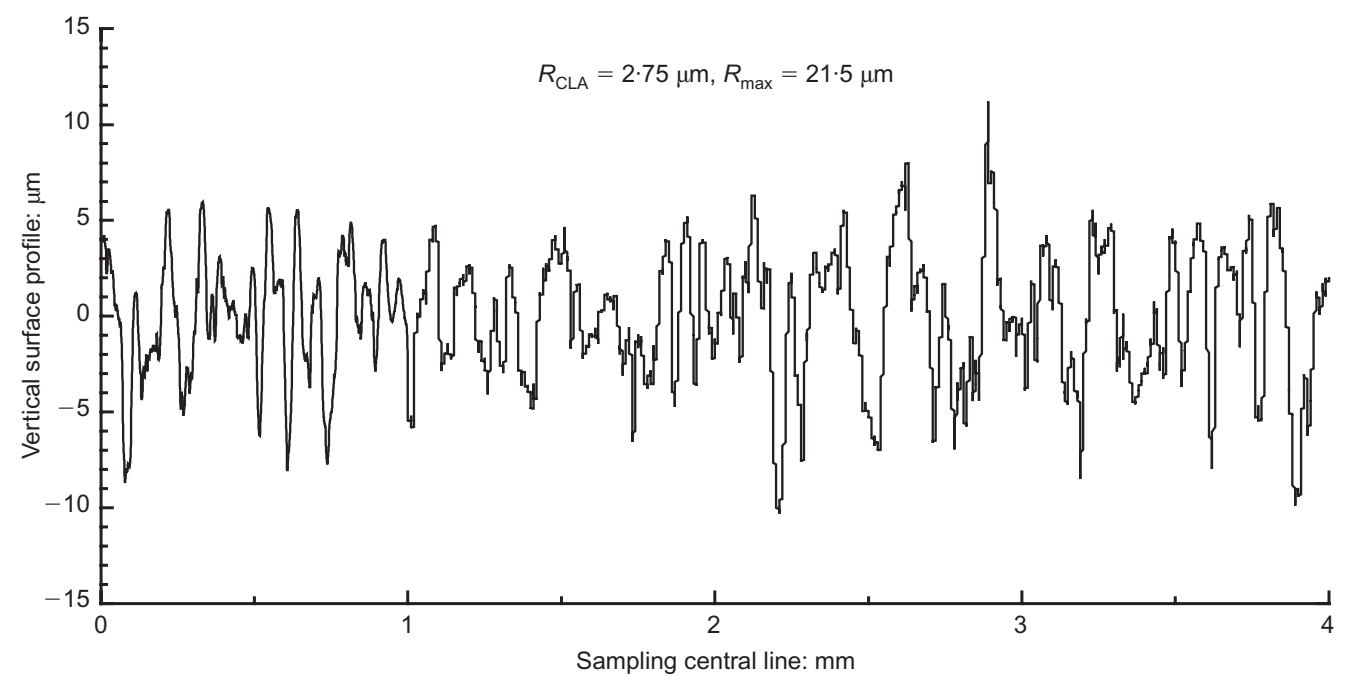

(b)

Fig. 14. Comparison of surface profile at mini-ICP2 tip: (a) before pile installation; (b) after pile installation 
test' profile with one from near the tip of the miniICP2. The larger asperities are eliminated and $R_{\max }$ (the vertical distance between the highest and lowest points) reduces from 32.9 to $21.5 \mu \mathrm{m}$, while $R_{\text {CLA }}$ reduces from 3.79 to $2.75 \mu \mathrm{m}$. Abrasion starts at a similar depth to zone 1 formation $(250$ and $50 \mathrm{~mm}$ in mini-ICP2 and 3 respectively) and roughness declines at a progressively reducing rate with pile penetration for both piles, despite their different histories of cyclic loading, see Fig. 15.

\section{RING-SHEAR INTERFACE TESTS}

The parallel interface ring-shear programme summarised in Table 2 was run with the Bishop et al. (1971) apparatus with oversized annular stainless steel interfaces. The latter were air abraded following the same specification as the pile, giving $R_{\text {CLA }}$ values of $3.1 \pm 0.3 \mu \mathrm{m}$, around $0.7 \mu \mathrm{m}$ below those for the pile.

The $14.1 \mathrm{~mm}$ high sand samples were placed to achieve $D_{\mathrm{r}} \sim 72 \%$. Normal stresses from 100 to $800 \mathrm{kPa}$ were applied and the samples sheared at $0.015 \mathrm{~mm} / \mathrm{s}$ with the gap between the confining rings and the interface held open, for about
$0.3 \mathrm{~mm}$. The gap was then closed to limit soil loss and the tests sheared at $0.37 \mathrm{~mm} / \mathrm{s}$ to the required final shear displacement (between $20 \mathrm{~mm}$ and $10 \mathrm{~m}$ ). Shearing was slowed and the gap reopened whenever accurate measurements were required. Water was temporarily placed in the cells at the end of testing so that capillary tensions would maintain the samples' integrity. Photographs were taken during dismantling and the thickness of any shear zone logged; small samples were also taken for QicPic grading analyses. Talysurf roughness profiles were established for the interfaces, which were air abraded again before the next testing.

Ring-shear tests on sands are subject to variation. Tests at common normal stress levels and displacements gave $\delta^{\prime}$ values that varied from means by up to $1 \cdot 7^{\circ}$; see Table 2 . However, the average values for the $5 \mathrm{~mm}$ displacement levels increase marginally from around $25^{\circ}$ at $100 \mathrm{kPa}$ to $26^{\circ}$ at $800 \mathrm{kPa}$. The effects of stress level are reduced in the analysis shown in Fig. 16 by normalising the ultimate $\tan \delta_{\mathrm{CV}}^{\prime}$ values by the average $5 \mathrm{~mm}$ displacement value (for that normal stress). Fine NE34 sand shows little variation with displacement, unlike some coarser sands (see Ho, 2007). The $800 \mathrm{kPa}$ experiments indicate a slight upward trend, but the overall large-displacement average value of

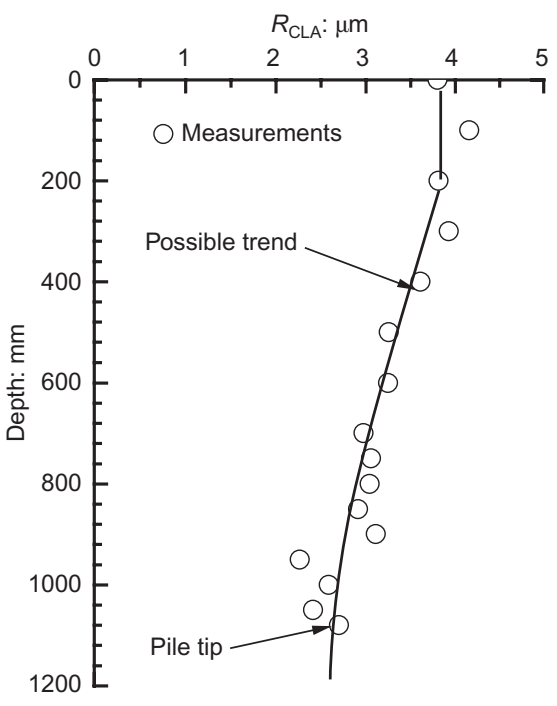

(a)

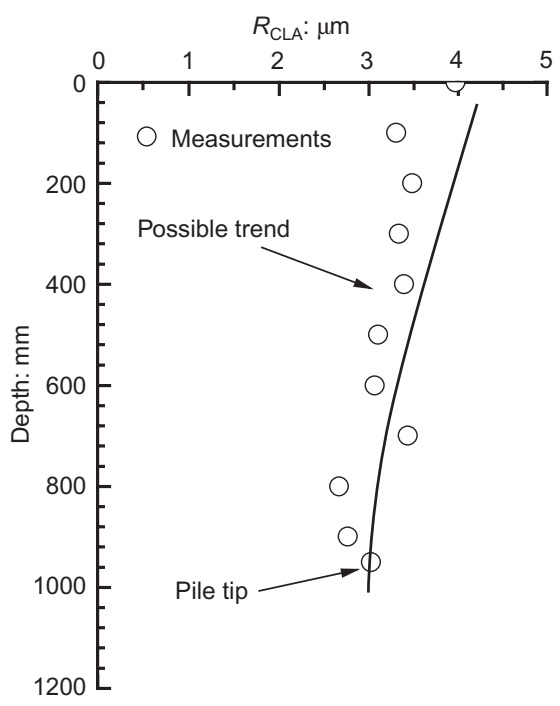

(c)

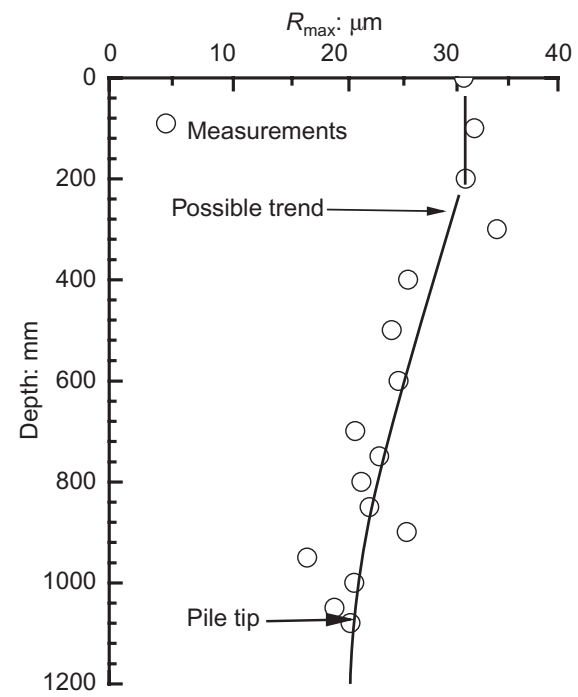

(b)

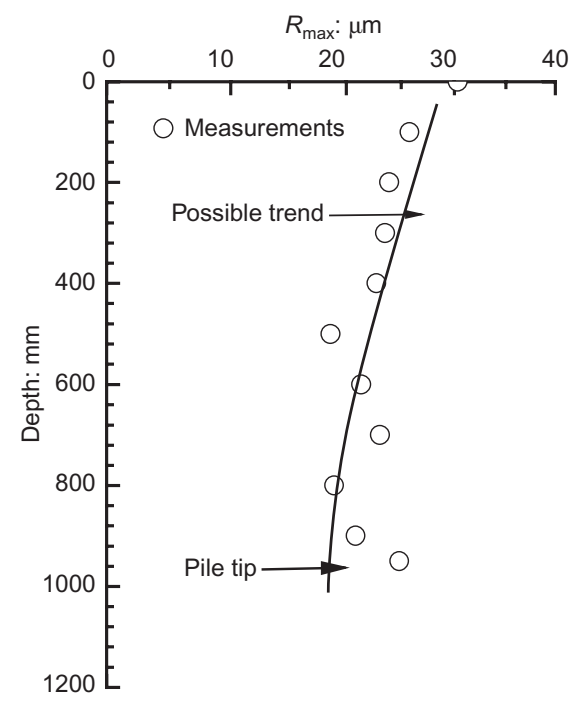

(d)

Fig. 15. Variation of roughness along pile shaft: (a) and (b) mini-ICP2; (c) and (d) miniICP3 
Table 2. Interface ring-shear test programme

\begin{tabular}{|c|c|c|c|c|c|c|}
\hline Test code & $\sigma_{n}^{\prime}: \mathrm{kPa}$ & $\begin{array}{l}\text { Maximum shear } \\
\text { displacement: } \mathrm{mm}\end{array}$ & $\begin{array}{c}\text { Average } \delta_{5 \mathrm{~mm}}^{\prime} \text { at } 5 \mathrm{~mm} \\
\quad \text { displacement: } \mathrm{deg}\end{array}$ & $\begin{array}{c}\delta_{\mathrm{CV}}^{\prime} \text { at full } \\
\text { displacement: deg }\end{array}$ & $\begin{array}{c}\text { Initial } R_{\mathrm{CLA}}: \\
\mu \mathrm{m}\end{array}$ & $\begin{array}{c}\text { Final } R_{\mathrm{CLA}}: \\
\mu \mathrm{m}\end{array}$ \\
\hline $\begin{array}{l}\text { RS100-200 } \\
\text { RS100-500 } \\
\text { RS100-1000 } \\
\text { RS100-2000 } \\
\text { RS200-200 } \\
\text { RS200-500 } \\
\text { RS200-1000 } \\
\text { RS200-2000 } \\
\text { RS400-200 } \\
\text { RS400-500 } \\
\text { RS400-1000 } \\
\text { RS400-2000 } \\
\text { RS800-20 } \\
\text { RS800-100 } \\
\text { RS800-200 } \\
\text { RS800-500 } \\
\text { RS800-1000 } \\
\text { RS800-10000 }\end{array}$ & $\begin{array}{l}400 \\
800\end{array}$ & $\begin{array}{c}200 \\
500 \\
1000 \\
2000 \\
200 \\
500 \\
1000 \\
2000 \\
200 \\
500 \\
1000 \\
2000 \\
20 \\
100 \\
200 \\
500 \\
1000 \text { (ageing) } \\
10000\end{array}$ & $\begin{array}{l}25 \cdot 5 \\
25 \cdot 7 \\
25 \cdot 9\end{array}$ & $\begin{array}{c}24 \cdot 4 \\
27 \cdot 0 \\
22 \cdot 5 \\
24 \cdot 0 \\
24 \cdot 2 \\
23 \cdot 5 \\
26 \cdot 5 \\
23 \cdot 9 \\
26 \cdot 5 \\
24 \cdot 9 \\
25 \cdot 2 \\
24 \cdot 8 \\
25 \cdot 8 \\
26 \cdot 8 \\
27 \cdot 0 \\
27 \cdot 0 \\
26 \cdot 7 \\
26 \cdot 8 \text { (ageing) } \\
28 \cdot 6\end{array}$ & $\begin{array}{l}3 \cdot 100 \\
2 \cdot 923 \\
2 \cdot 994 \\
3 \cdot 139 \\
3 \cdot 024 \\
3 \cdot 381 \\
3 \cdot 254 \\
3 \cdot 268 \\
3 \cdot 103 \\
2 \cdot 990 \\
3 \cdot 072 \\
3 \cdot 119 \\
3 \cdot 167 \\
3 \cdot 175 \\
2 \cdot 882 \\
2 \cdot 834 \\
3 \cdot 086 \\
3 \cdot 199\end{array}$ & $\begin{array}{l}3 \cdot 100 \\
2 \cdot 923 \\
2 \cdot 891 \\
2 \cdot 892 \\
2 \cdot 837 \\
2 \cdot 976 \\
2 \cdot 843 \\
2 \cdot 440 \\
2 \cdot 641 \\
2 \cdot 360 \\
2 \cdot 022 \\
1 \cdot 711 \\
2 \cdot 908 \\
2 \cdot 694 \\
2 \cdot 283 \\
1 \cdot 856 \\
1 \cdot 492 \\
\\
0 \cdot 876\end{array}$ \\
\hline
\end{tabular}

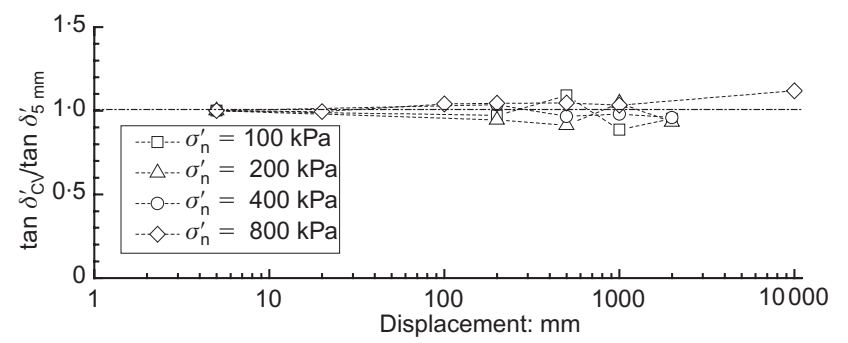

Fig. 16. Comparisons of initial and full displacement interface shear angles

$\delta_{\mathrm{CV}}^{\prime}=25 \cdot 5^{\circ}$ falls marginally below that from the pile instruments and the mean value found by Ho (2007) with steel interfaces. It falls more significantly $\left(3.5^{\circ}\right)$ below the value suggested by Kolk et al. (2005a); it is also interesting to note that a sample sheared to $1000 \mathrm{~mm}$ under $800 \mathrm{kPa}$, and aged under load for 20 days, showed the same $\delta_{\mathrm{CV}}^{\prime}$.

Talysurf measurements presented in Fig. 17 show interface $R_{\text {CLA }}$ values reducing systematically with normal stress and shear displacement. The $800 \mathrm{kPa}$ tests show the clearest, approximately semi-logarithmic, trend with $R_{\mathrm{CLA}}$ reducing $<1 \mu \mathrm{m}$ within $10 \mathrm{~m}$. The pile roughness trend is also shown. After correcting for the $0.7 \mu \mathrm{m}$ variation between the initial

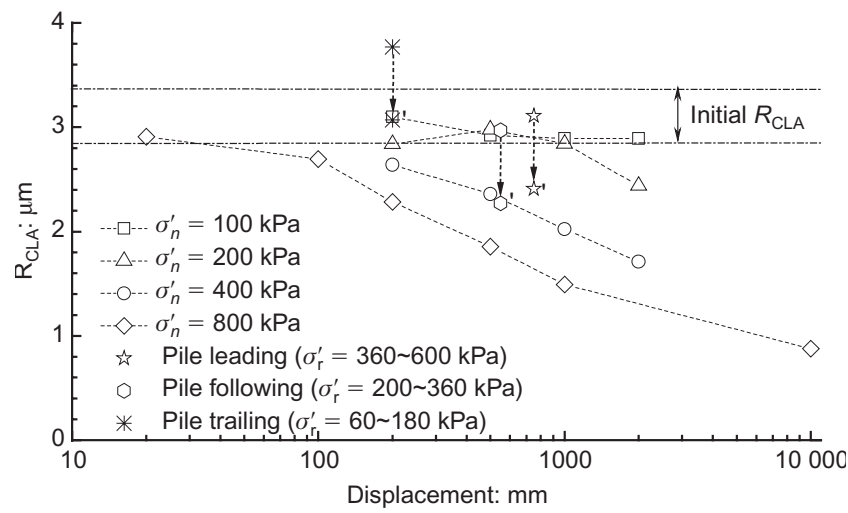

Fig. 17. Roughness changes from ring-shear and pile tests. Data annotated with prime symbol have been corrected to allow for $0.7 \mu \mathrm{m}$ difference in initial roughness roughnesses of the pile-ring-shear interfaces, and subtracting the first $250 \mathrm{~mm}$ of penetration through the low $q_{\mathrm{c}}$ sand, the pile and ring-shear experiments show the same trends.

Thin grey interface shear zones were evident on dismantling that were sharply differentiated from the overlying buff sand, see Fig. 18. The specimens were sampled carefully, removing first all material from the overlying sand down to $2.3 \mathrm{~mm}$ above the interface (the upper part), then the sand found between this level and the top of zone I (the mid part), and finally the zone I material. The zone I thicknesses were measured by caliper, giving the results shown in Fig. 19. While generally thinner than the sleeve of fractured material generated in the pile tests, the ring-shear thicknesses generally increased with normal stress level and displacement, growing in the $800 \mathrm{kPa}$ test to $\sim 1.5 \mathrm{~mm}$ after $10 \mathrm{~m}$ of displacement. The ring-shear trends suggest that zone 1 thickness should grow by up to $0.5 \mathrm{~mm}$ under the pile normal stress and displacement conditions acting on the pile shaft as a result of continuing penetration, broadly matching the observations made with the mini-ICP3. The greater final thickness noted on mini-ICP2 may be related to the 100 large-displacement cycles applied at the end of this experiment.

While the ring-shear zone I samples had the same grey colour as the pile zone 1 material, the QicPic particle

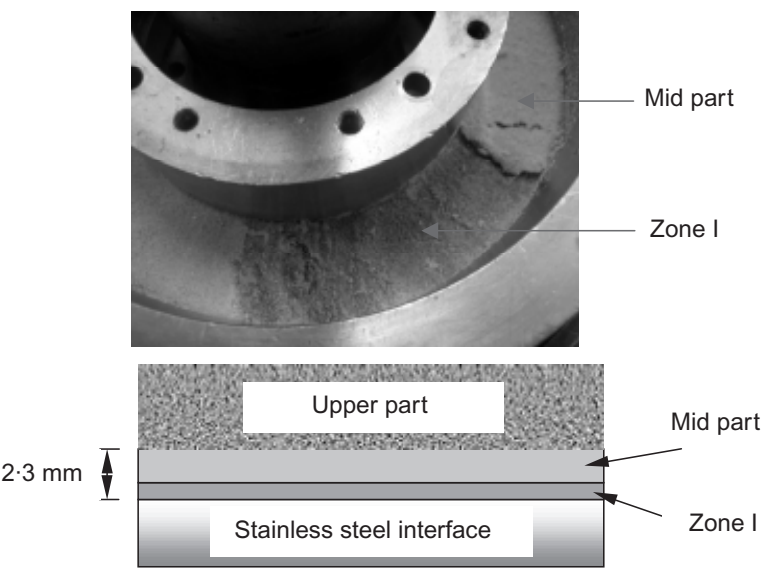

Fig. 18. Zone I and mid part of ring shear test 


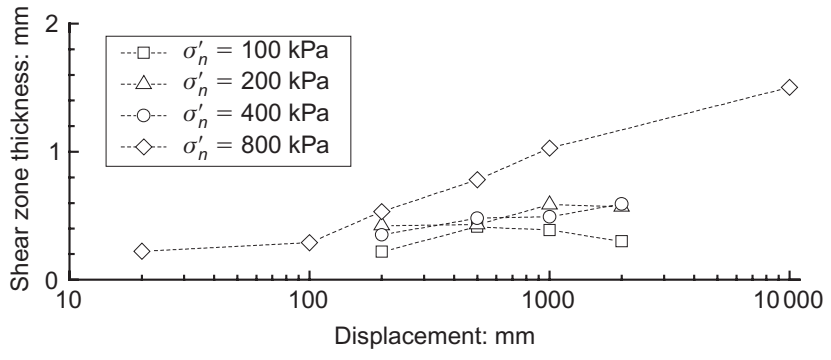

Fig. 19. Shear zone (zone I) development - thicknesses of crushed material in ring shear as function of normal stress level and displacement

gradings are generally far closer to those of the fresh sand. Less than 2 and $3 \%$ was finer than 63 or $100 \mu \mathrm{m}$ respectively in tests up to $400 \mathrm{kPa}$, irrespective of the shear deformation, see Figs 20 and 21 . Only the $800 \mathrm{kPa}$ tests produced distributions comparable to the pile zone 1 sand. X-ray diffraction analyses of zone I samples (after $1 \mathrm{~m}$ of displacement under $800 \mathrm{kPa}$ ) showed a marginally higher concentration of abraded steel particles, with the silica content falling from $99 \cdot 7 \%$ (fresh sand) to $99 \cdot 3 \%$. The samples taken above the zone I boundary showed little or no fine material in the mid or upper part samples, even in the $800 \mathrm{kPa}$ test, see Fig. 22. Parallel tests in which the interface was mounted above the sample show insignificant fines migration beyond the zone 1 boundary, even when assisted by gravity (Ho, 2007). Whether more particles would migrate under dynamic driving conditions is open to speculation.

The changes in interface roughness and grain sizes led to general reductions in the roughness ratios $R_{\mathrm{CLA}} / D_{50}$ and

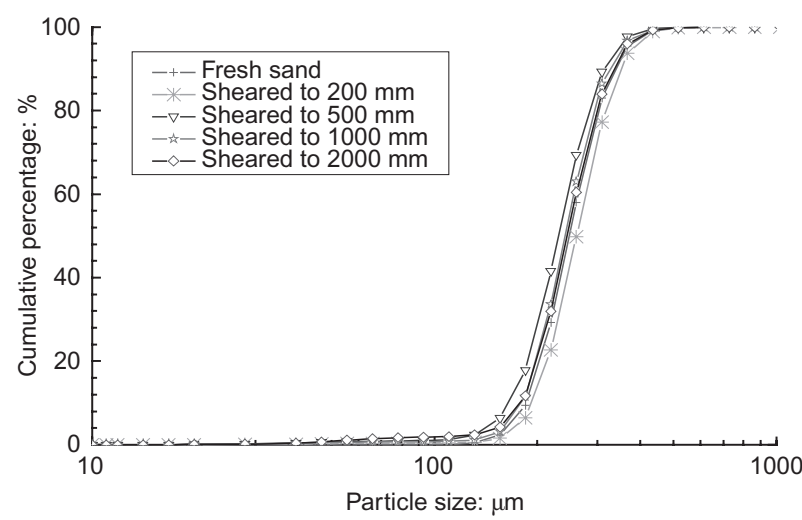

(a)

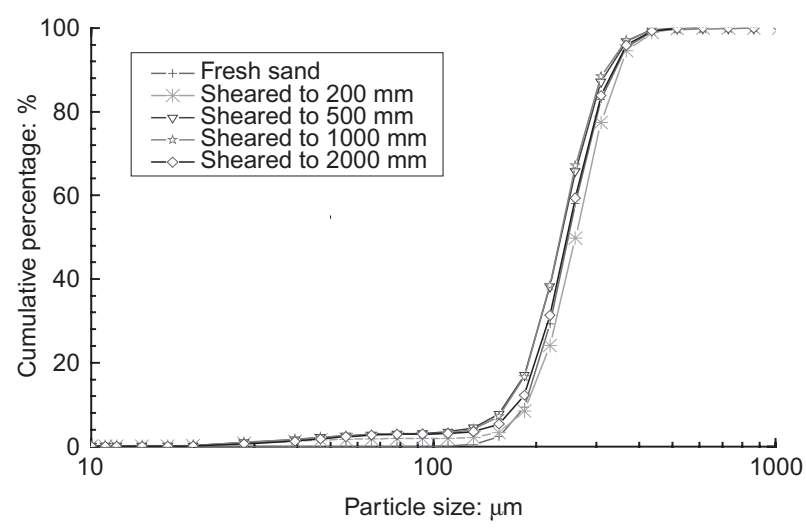

(c)
$R_{\mathrm{CLA}} / D_{10}$ that were clearer in the latter. Fig. 23 illustrates the trends seen for these parameters in the pile test. Given that only minor changes were seen in the overall $\delta^{\prime}$ values as shearing progressed, it appears that any correlation between roughness and $\tan \delta^{\prime}$ is best made in terms of $R_{\mathrm{CLA}} / D_{50}$.

\section{SUMMARY AND CONCLUSIONS}

Particle-scale investigations have been made of sand around displacement piles, and of the pile surfaces after installation. Ring-shear interface tests have established how stress level and displacement history may affect the sand interface shearing characteristics along the pile shaft. The main findings are listed below.

(a) Considerable grain crushing takes place beneath the tip during installation, provided the sand is sufficiently dense and pressurised. With NE34 Fontainebleau silica sand the threshold CPT $q_{\mathrm{c}}$ value appears to be around $5 \mathrm{MPa}$.

(b) The crushed material is displaced radially as the pile tip advances, developing concentric zones around the pile shaft involving different degrees of particle crushing, which were established by an optical technique, adopting the Feret minimum dimension as the key parameter.

(c) The first zone of modified sand was distinguished by its colour, broader grading, compact nature and adherence to the pile shaft. More that $15 \%$ compaction was assessed to have taken place under the high compressive tip stresses and extreme shearing. The grey colour is thought to result from particle surface abrasion.

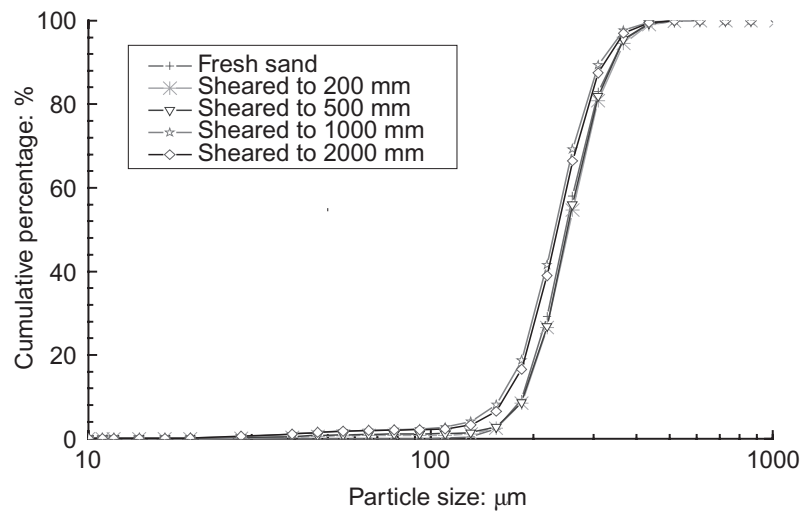

(b)

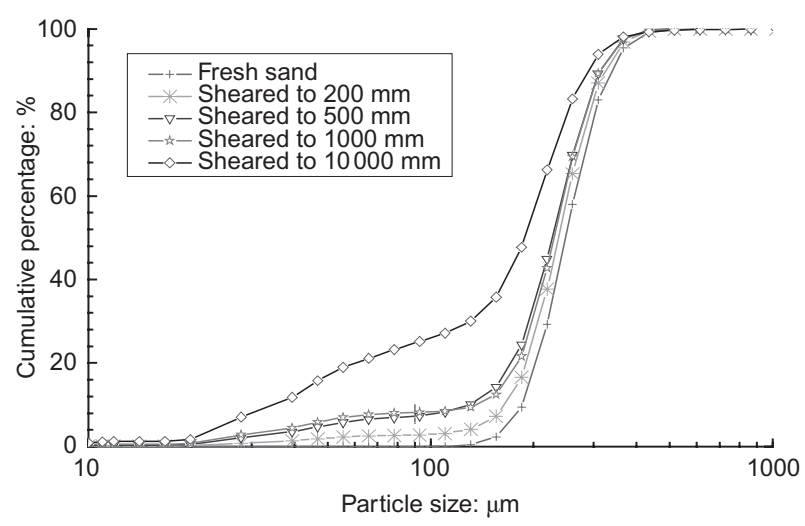

(d)

Fig. 20. Particle size distributions of ring-shear zone I samples: (a) $\sigma_{n}^{\prime}=100 \mathrm{kPa} ;(\mathrm{b}) \sigma_{n}^{\prime}=200 \mathrm{kPa} ;(\mathrm{c}) \sigma_{n}^{\prime}=400 \mathrm{kPa}$; (d) $\sigma_{n}^{\prime}=800 \mathrm{kPa}$ 

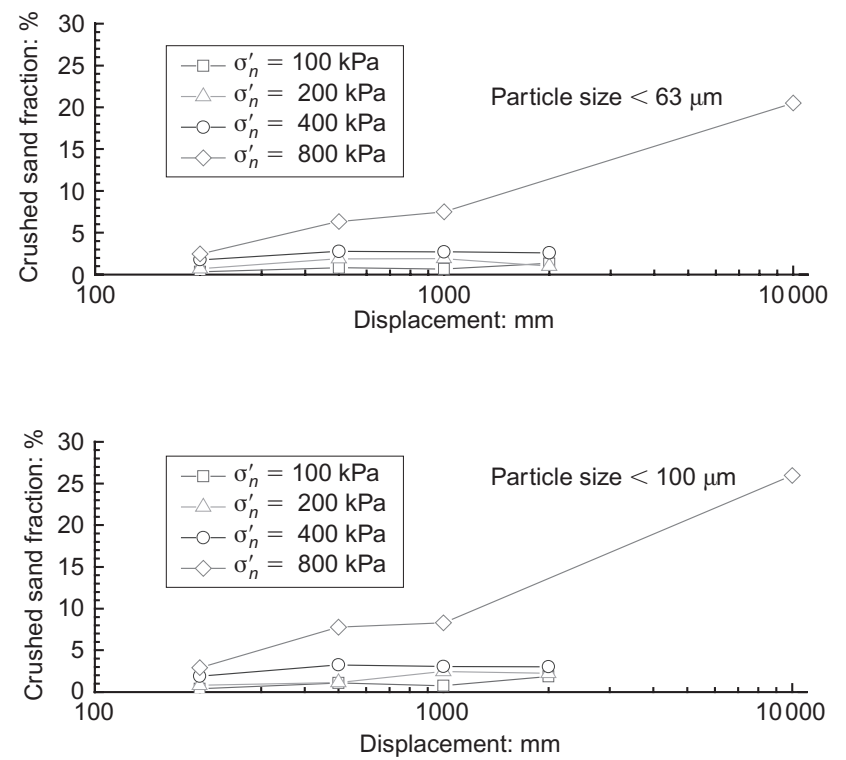

Fig. 21. Finer sand fractions in zone $I$ of ring-shear test

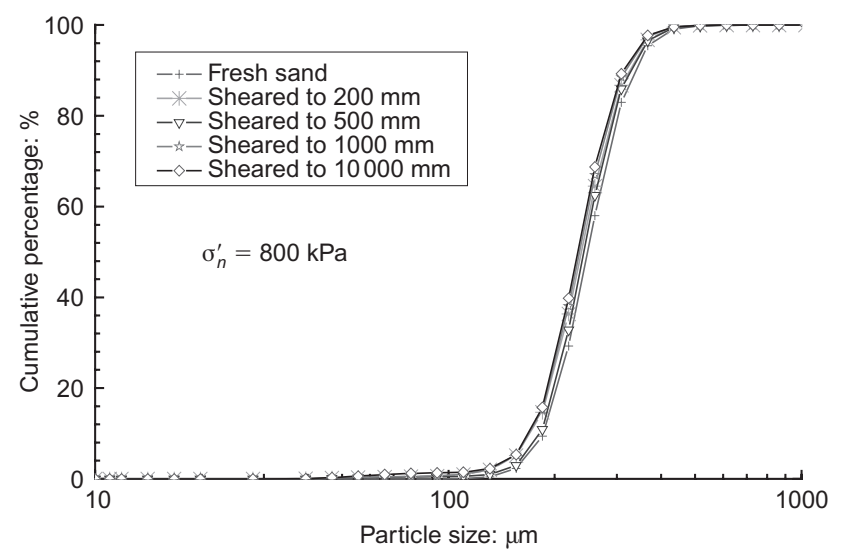

Fig. 22. Change of particle size distribution of ring-shear Mid part samples $\left(\sigma_{n}^{\prime}=800 \mathrm{kPa}\right)$

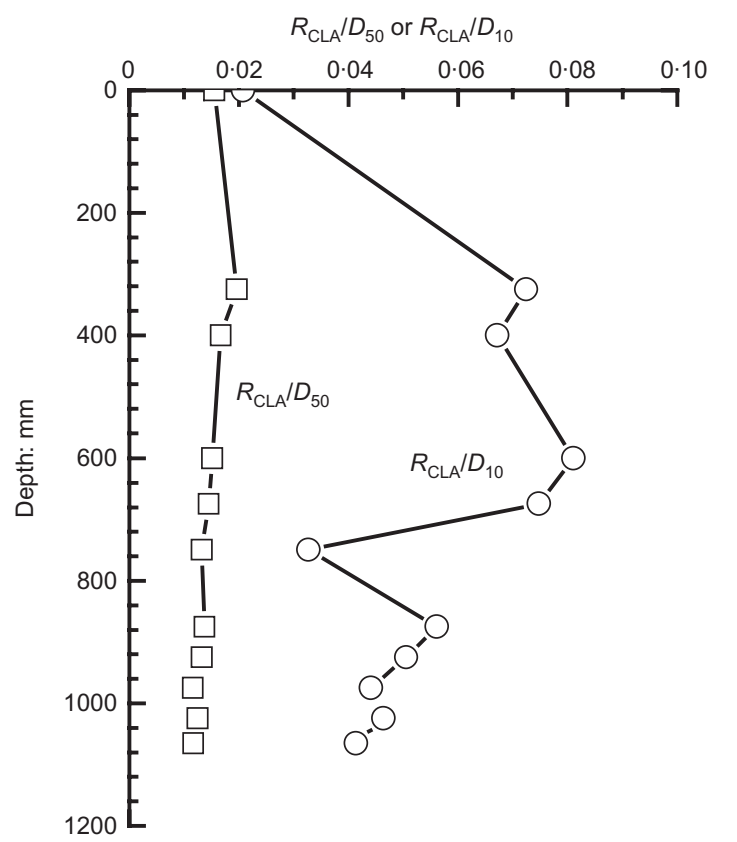

Fig. 23. Normalised roughness ratios plotted against depth from mini-ICP2 (d) The shear zone thickness developed near the tip appears to scale with particle size. The 'near-tip' thicknesses found by the present authors and White \& Bolton (2004) both amount to $\approx 2 \cdot 4 D_{50}$ and are thought to have been thicker $\left(\approx 4 D_{50}\right)$ over the conical face where they are generated beneath the tip. The zone thickness grows with $h / R$, particularly when installation is not monotonic, and is augmented by later static and cyclic loading. The zone 1 shear zone maintains a sharply defined outer boundary as it grows in thickness.

(e) Around $20 \%$ of the zone 1 samples comprised finesand- to silt-sized crushing products, of which $<1 \%$ originated from abraded steel.

(f) A second, thicker, zone of modified material, which comprised 6-8\% of broken fine sand, could be identified around the pile through its ability to adhere to the shaft by suction when moistened by mist spray. The outer zone 3 material comprised a lower proportion of fine breakage products. No colour alteration was noted in zones 2 or 3 .

( $g$ ) As with field tests on instrumented piles, sand positioned under the model pile experienced first intense axial compression before being displaced laterally by the advancing tip and undergoing dramatic radial stress reductions as the pile shoulder passed. These changes are interpreted as being the result of strain path reversals (Baligh, 1985; White \& Bolton 2004), compounded by shear band compaction including particle breakage and time-dependent sand behaviour (creep compression and stress relaxation).

(h) The shearing action imposed by installation load cycles combines with continuing creep compression and stress relaxation to give further reductions in radial effective stress at $h / R$ levels well above the tip, where insignificant straining would be expected from strain path analyses. Radial growth of the zone 1 shear band is likely to generate compressive radial strains that contribute to the continuing decline in radial stresses with $h / R$ increases. Similar features are likely to apply under large-displacement cyclic loading.

(i) The concentration of particle breakage and compaction into shear bands of thickness related to particle size may lead to important scale effects applying to the stress regime developed around the pile shaft.

(j) The sand around the shaft is left in a highly overconsolidated state at the end of installation. The zone 1 material has a final void ratio well below the sand's initial $e_{\min }$ value and a higher relative density with respect to its modified index void ratios. The response to further static loading is likely to be strongly dilatant.

(k) Monotonic ring-shear interface tests generate a grey interface layer that is comparable to the pile zone 1 material. While the ring-shear thicknesses and crushed fine fractions increase with normal stress level and displacement, tests that match the pile shaft normal stresses and shear displacements lead to generally thinner shear zones, lower proportions of fractured sand and marginally higher proportions of abraded steel.

(l) Non-monotonic cyclic ring shear tests are likely to generate more particle breakage, but do not model the high-pressure particle crushing and shear band development that takes place just ahead of the pile tip during penetration.

(m) Monotonic large-displacement ring-shear tests give broadly similar patterns of interface roughness modification and closely comparable values of $\delta_{\mathrm{CV}}^{\prime}$ to the pile, offering good predictions for practical pile design. 


\section{ACKNOWLEDGEMENTS}

The authors acknowledge gratefully the sponsorship and technical discussion provided by the Engineering and Physical Sciences Research Council (EPSRC), Centre National de la Recherche Scientifique (CNRS), the Health and Safety Executive (HSE), Shell (UK) and Total France. They also wish to thank their many colleagues at Imperial College and INGP Grenoble for their contributions to the research described. The first author is grateful for the NSFC travel grant through project no. 50808159.

\section{REFERENCES}

Åstedt, B., Weiner, L. \& Holm, G. (1992). Increase in bearing capacity with time for friction piles in silt and sand. Proceedings of the 11th Nordic geotechnical meeting, Aalborg, Denmark, May 28-30, pp. 411-416.

Baligh, M. M. (1985). Strain path method. J. Soil Mech. Found. Div., ASCE 111, No. 9, 1108-1136.

Bishop, A., Green, G., Garga, V., Anderson, A. \& Brown, J. (1971). A new ring shear apparatus and its application of the measurement of the residual strength. Géotechnique 21, No. 4, 273328, doi: 10.1680/geot.1971.21.4.273.

Chow, F. C. (1997). Investigation into displacement pile behaviour for offshore foundations. PhD thesis, Imperial College, London, UK.

Chow, F. C., Jardine, R. J., Nauroy, J. F. \& Brucy, F. (1997). Timerelated increases in the shaft capacities of driven piles in sand. Géotechnique 47, No. 2, 353-361, doi: 10.1680/geot.1997.47. 2.353.

Clausen, C. J. F., Aas, P. M. \& Karlsrud, K. (2005). Bearing capacity of driven piles in sand, the NGI approach. In Frontiers in offshore geotechnics (eds S. Gourvenec \& M. Cassidy), pp. 677-681. London: Taylor \& Francis

Colliat-Dangus, J. L., Desrues, J. \& Foray, P. (1988). Triaxial testing of granular soils under elevated cell pressure. In Advanced triaxial testing of soil and rock, ASTM STP 977 (eds R. T. Donaghe, R. C. Chaney \& M. L. Silver), pp. 290-310. Philadelphia: ASTM.

Coop, M. R. (2005). On the mechanics of reconstituted and natural sands. In Deformation characteristics of geomaterials (eds H. Di Benedetto, T. Doanh, H. Geoffroy \& C. Sauzéat), pp. 29-58. The Netherlands: AA Balkema.

CUR (Centre for Civil Engineering Research and Codes) (2001). Bearing capacity of steel pipe piles, Report 2001-8. Gouda, The Netherlands: Centre for Civil Engineering Research and Codes.

Gasparre, A., Coop, M. R. \& Cotecchia, F. (2003). An experimental investigation of creep processes in a crushable sand. In Deformation characteristics of geomaterials (eds $\mathrm{H}$. Di Benedetto, T. Doanh, H. Geoffroy \& C. Sauzéat), pp. 773-778. The Netherlands: AA Balkema.

Gaudin, C., Schnaid, F. \& Garnier, J. (2005). Sand characterization by combined centrifuge and laboratory tests. Int. J. Phys. Modelling Geotech. 5, No. 1, 42-56.

Gavin, K. G. \& Lehane, B. M. (2003a). The shaft capacity of pipe piles in sand. Can. Geotech. J. 40, No. 1, 36-45.

Gavin, K. G. \& Lehane, B. M. (2003b). End bearing of small pipe piles in dense sand. Proceedings of the BGA international conference on foundations, innovations, observations, design and practice, pp. 321-330. London: Thomas Telford.

Gavin, K. G. \& O'Kelly, B. C. (2007). Effect of friction fatigue on pile capacity in dense sand. J. Geotech. Geoenviron. Engng, ASCE 133, No. 1, 63-71.

Ho, T. Y. K. (2007). Study of the shear behaviour of sand-steel interfaces by ring shear tests. MSc dissertation, Imperial College, London, UK.

Jardine, R. J. \& Chow, F. C. (1996). New design methods for offshore piles, MTD Publication 96/103. London: MTD (Marine Technology Directorate) Ltd.
Jardine, R. J. \& Chow, F. C. (2007). Some recent developments in offshore pile design. Proc. 6th Int. Offshore Site Investigation and Geotech. Conf:: Confronting New Challenges and Sharing Knowledge, London, 303-332.

Jardine, R. J., Chow, F. C., Overy, R. F. \& Standing, J. R. (2005). ICP design methods for driven piles in sands and clays. London: Thomas Telford.

Jardine, R. J., Lehane, B. M \& Everton, S. J. (1992). Friction coefficients for piles in sands and silts. Proceedings of international conference on offshore site investigation and foundation behaviour (ed. D. A. Ardus), pp. 661-677. London: Kluwer Academic Publishers.

Jardine, R. J., Standing, J. R. \& Chow, F. C. (2006). Some observations of the effects of time on the capacity of piles driven in sand. Géotechnique 56, No. 4, 227-244, doi: 10.1680/ geot.2006.56.4.227.

Kishida, H. \& Uesugi, M. (1987). Tests of the interface between sand and steel in the simple shear apparatus. Géotechnique 37, No. 1, 45-52, doi: $10.1680 /$ geot.1987.37.1.45.

Klotz, E. U. \& Coop, M. R. (2001). An investigation of the effect of soil state on the capacity of driven piles in sands. Géotechnique 51, No. 9, 733-751, doi: 10.1680/geot.2001.51.9.733.

Kolk, H. J., Baaijens, A. E. \& Senders, M. (2005a). Design criteria for pipe piles in silica sands. In Frontiers in offshore geotechnics (eds S. Gourvenec \& M. Cassidy), pp. 711-716. London: Taylor \& Francis.

Kolk, H. J., Baaijens, A. E. \& Vergobbi, P. (2005b). Results from axial load tests on pipe piles in very dense sands: the EURIPIDES JIP. In Frontiers in offshore geotechnics (eds S. Gourvenec \& M. Cassidy), pp. 661-667. London: Taylor \& Francis.

Lambe, T. W. \& Whitman, R. V. (1969). Soil mechanics. London: Wiley.

Lane, K. S. \& Washburn, S. E. (1946). Capillarity tests by capillarimeters and by soil filled tubes. Proc. 26th Ann. Meeting Highway Res. Board, Washington, DC, 460-473.

Lehane, B. M. (1992). Experimental investigations of pile behaviour using instrumented field piles. $\mathrm{PhD}$ thesis, University of London (Imperial College), London.

Lehane, B. M. \& Jardine, R. J. (1994). Shaft capacity of driven piles in sand: a new design approach. Proc. 7th Int. Conf. on Behaviour of Offshore Structs, Boston 1, 23-36.

Lehane, B. M., Jardine, R. J., Bond, A. J. \& Frank, R. (1993). Mechanisms of shaft friction in sand from instrumented pile test. J. Geotech. Geoenviron. Engng 119, No. 1, 19-35.

Lehane, B. M., Schneider, J. A. \& Xu, X. (2005). A review of design methods in offshore driven piles in siliceous sand, Report GEO 05358, p. 105. University of Western Australia (UWA).

Lings, M. L. \& Dietz, M. S. (2005). The peak strength of sand steel interfaces and the role of dilation. Soils Found. 46, No. 6, $1-14$.

Marechal, O. (1999). Étude de la capacite portante de fondation superficielles etablies en bord de pente et soumises a des chargements complexes. PhD thesis, École Centrale de Nantes, Universite de Nantes.

White, D. J. \& Bolton, M. D. (2002). Observing friction fatigue on a jacked pile. In Centrifuge and constitutive modelling: two extremes (ed. S. M. Springman), pp. 347-354. Rotterdam: Swets $\&$ Zeitlinger.

White, D. J. \& Bolton, M. D. (2004). Displacement and strain paths during plane-strain model pile installation. Géotchnique 54, No. 6, 375-397, doi: 10.1680/geot.2004.54.6.375.

White, D. J. \& Lehane, B. M. (2004). Friction fatigue on displacement piles in sand Géotechnique 54, No. 10, 645-658, doi: 10.1680/geot.2004.54.10.645.

White, D. J., Schneider, J. A. \& Lehane, B. M. (2005). The influence of effective area ratio on shaft friction of displacement piles in sand. In Frontiers in offshore geotechnics (eds S. Gourvenec \& M. Cassidy), pp. 741-747. London: Taylor \& Francis. 